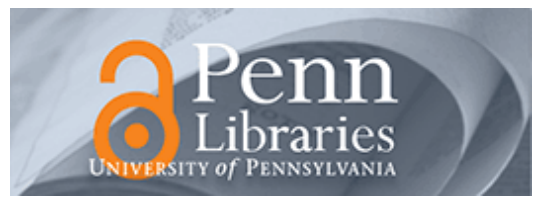

University of Pennsylvania

ScholarlyCommons

Real Estate Papers

Wharton Faculty Research

8-2005

\title{
Listening to What the World Says: Bilingualism and Earnings in the United States
}

Albert Saiz

University of Pennsylvania

Elena Zoido

Follow this and additional works at: https://repository.upenn.edu/real-estate_papers

Part of the Economics Commons, and the Other Languages, Societies, and Cultures Commons

\section{Recommended Citation}

Saiz, A., \& Zoido, E. (2005). Listening to What the World Says: Bilingualism and Earnings in the United States. The Review of Economics and Statistics, 87 (3), 523-538. http://dx.doi.org/doi:10.1162/ 0034653054638256

This paper is posted at ScholarlyCommons. https://repository.upenn.edu/real-estate_papers/55

For more information, please contact repository@pobox.upenn.edu. 


\title{
Listening to What the World Says: Bilingualism and Earnings in the United States
}

\author{
Abstract \\ Is there a shortage of critical foreign language skills in the United States? Recent concerns about national \\ security and economic globalization suggest increased demand and wage premia for foreign language \\ speakers. The use of English as the international language, however, suggests a decrease in demand for \\ foreign language skills in the United States. To address this question, we study a representative sample of \\ U.S. college graduates. Ordinary least squares regressions with controls for cognitive ability, \\ nonparametric methods based on the propensity score, and panel data methods suggest a $2 \%-3 \%$ wage \\ premium for college graduates who can speak a second language. \\ Disciplines \\ Economics | Other Languages, Societies, and Cultures
}




\title{
ROOM IN THE KITCHEN FOR THE MELTING POT: IMMIGRATION AND RENTAL PRICES
}

\author{
Albert Saiz*
}

\begin{abstract}
This paper studies the response of housing markets to immigration shocks. Following Card (1990), I examine the changes in rental prices in Miami and three comparison groups after the Mariel boatlift. This exogenous immigration shock added an extra 9\% to Miami's renter population in 1980. I find that rents increased from $8 \%$ to $11 \%$ more in Miami than in the comparison groups between 1979 and 1981. By 1983 the rent differential was still $7 \%$. Rental units of higher quality were not affected by the immigration shock. Units occupied by low-income Hispanic residents in 1979 experienced an extra 8\% differential hike with respect to other low-income units. Relative housing prices moved in the opposite direction from rents in the short run.
\end{abstract}

\section{Introduction}

$\mathrm{T}$ HE economics literature on the impact of immigration has focused on its implications for the labor market. But much less is known about its effect on local prices. This paper considers the impact of immigration on housing markets: does it change rents and home values and thus affect the real wages and wealth of previous residents?

Immigration in the United States and other industrialized countries boosts housing demand, especially for rental units. In the United States the number of new immigrant households moving into rental units was greater than the full increase in the number of rentals between 1996 and 1999. This implies that immigrant households accounted for all new demand in this period. In the northeast and western regions, the foreign-born represented $28 \%$ of renter households in 1999, up from $15 \%$ percent in $1980 .{ }^{1}$

This paper provides evidence of the short-run effect of immigration on rental markets. It finds a positive correlation between immigration inflows in U.S. metropolitan areas and changes in rents for rental units of moderate quality. This result holds controlling for changes in income, changes in population, and a proxy for expectations of future growth. To address concerns over the endogeneity of immigration inflows, and following the approach in Card (1990), I make

Received for publication March 19, 2001. Revision accepted for publication May 20, 2002.

* Department of Economics, Harvard University; Federal Reserve Bank of Philadelphia.

This paper is based on Chapter 1 of my dissertation (Saiz, 2002) and does not necessarily represent the views of the Federal Reserve Bank of Philadelphia or the Federal Reserve System. Thanks to Christopher Jencks, David Cutler, and Ed Glaeser for comments and support. George Akerloff, George Borjas, two anonymous referees, Diego Comín, Katherine Newman, Emmanuel Saez, Tara Watson, and participants at the Harvard Labor Economics Workshop and the Harvard Kennedy School Inequality Proseminar provided helpful comments and suggestions. They could not help the remaining errors, which are attributable only to the author. The author acknowledges funding from the Graduate Program in Inequality and Social Policy (Harvard Kennedy School) and the Lincoln Institute of Land Policy. Months after the submission of this paper to the RESTAT, I learned about independent work in progress on the impact of the Mariel boatlift on rents by Scott Susin. It is reassuring that we found similar results working independently.

${ }^{1}$ These figures are from Joint Center for Housing Studies (2000). use of the Mariel boatlift in the Miami metropolitan area. I document a sharp increase in local rental prices associated with this immigration shock. The immigrants from Mariel increased the renter population of Miami by at least $9 \%$ in one year (1980). From 1979 to 1981 rents increased in real terms by $8 \%$ to $11 \%$ percent more in Miami than in three groups of comparison metropolitan areas. This difference had fallen somewhat by 1983 , but was still about $7 \%$. The immigration shock, consisting mainly of unskilled Cuban nationals, seems to have had an even greater impact on housing units occupied in 1979 by poor Hispanic residents.

The results are important for understanding the short-run and medium-run local response of natives to substantial localized immigration. One of the main motivations of the literature on immigration and labor market outcomes is to examine the distributive impact of immigration. Most area studies find that immigration of workers with a certain skill level has little or no effect on the absolute and relative wages of the local population with similar skill levels (Altonji \& Card, 1991). Card (1990) used the Mariel boatlift as a quasi experiment to identify the impact of immigrants on wages and did not find any effect, even in the short run. At the same time, native workers seem to avoid and migrate out from areas with high levels of immigration (Filer, 1992). This suggests that the mobility of natives may counterbalance the theoretical short-run effects of immigration on local wages. ${ }^{2}$ But the fact that immigration shocks are quickly arbitraged away is itself surprising. If wages do not adjust in the short run, what motivates native workers to avoid the areas where immigrants concentrate? Workers take longer to react to other shocks in local labor markets (Blanchard \& Katz, 1992), and local wages seem to be responsive to labor market shocks in the short run (Topel, 1986). These observations prompt Borjas (1994) to argue that the main empirical puzzle arising from this literature is: "Why should it be that many other regional variations persist over time, but the impact of immigration on native workers is arbitraged away immediately?"

This problem suggests that we need to look at other markets and social interactions to understand the local impact and responses to immigration. Several studies have documented the existence of competition between lowincome immigrants and previous low-income residents for a variety of goods that are fixed in the short run. ${ }^{3}$ Housing is

\footnotetext{
${ }^{2}$ Borjas, Freeman, and Katz (1996) argue that the effects of immigration on local labor markets are spread out into the national labor market. These authors rely on a structural approach to find moderate effects of immigration on wages.

${ }^{3}$ For example, Borjas and Hilton (1996) and Hansen and Lofstrom (2000) examine the use of welfare benefits by immigrants in the United States and Sweden. Simon (1999, chapter 9) discusses the impact on
} 
the most important of such goods. To explain changes in the welfare and moving decisions of natives, both wages and rents have to be taken into account within an economic spatial equilibrium (Roback, 1982).

Consider the case of relatively unskilled immigrants. Existing literature (Borjas, 1994, 2000; National Research Council, 1997) argues that the average educational attainment of recent immigrants in the United States is below that of natives. Because of their relatively low earnings during their initial years in the host country, unskilled immigrants are disproportionately likely to demand lower-cost-and hence lower-quality-housing. The housing units that recent immigrants demand are usually rental apartments. The short-run supply of low-quality rentals is bound to be more inelastic than the overall housing supply. Thus, in a segmented housing market with different qualities (Sweeny, 1974; Braid, 1981; O'Flaherty, 1996), the effects of unskilled immigration in the short run may be stronger for low-quality units.

The fact that different quality segments of the housing markets may be differently affected by immigration is important. In the very short run, a low-skilled immigration shock is unlikely to change substantially the local demand for housing units of higher quality. Therefore, if one is interested in the real consumption wage of unskilled workers, it is important to look at changes in the costs of dwellings of moderate quality (usually rental units), rather than simply examine changes in overall local price indices or changes in average housing costs.

Empirically, I find that the overall average impact of the boatlift on real wages through changes in rents was modest, even in the short run: a reduction of $1.42 \%$. Nevertheless, as noted before, this impact was more important for households in the lower quartile of the renters' income distribution: $3.77 \%$.

The effects of immigration on housing markets can actually be better identified than the effects on labor markets. After all, it is not clear what is the counterfactual of immigration in the national labor market: international trade flows and domestic production are very much endogenous to the level of immigrant labor. Physical presence is the only indisputable characteristic of the immigrant labor input and has direct effects on housing markets, the spatial organization of neighborhoods, and social interactions (Zax, 1998; Jones-Correa, 2000). Thus, irrespective of the wage impact of immigration on previous residents, the interplay between immigrants and residential markets is a topic of considerable importance.

The paper is organized as follows. Section II presents a simple model that applies the idea of spatial equilibrium to the impact of immigration on rents in a segmented housing market. Section III describes the data sets that I use for the empirical analysis. Section IV presents some general evi-

natural resources and the environment. Hoxby (1998) analyzes the impact on admissions of native minorities to top colleges. dence about the correlation of immigrant inflows and rents and defines my empirical strategy. Section V describes the short-run changes in rental prices, the housing stock supply adjustment, and the changes in residential density during the years after the Mariel boatlift. I also describe the mediumrun adjustment after the boatlift. Section VI concludes the paper and discusses avenues for further research.

\section{A Model}

In this section I present a simplified model that helps to understand the effects of an immigration shock on the housing market. I focus on shocks that consist of unskilled individuals. The model uses the fact that housing units have different quality levels (Sweeny, 1974). As in Braid (1981), I use a bid-rent approach to examine the demand for quality by different income groups. I simplify Braid's (1981) approach by considering only two income groups and by using a quasi-linear utility function separable in income and tastes for housing quality. My focus is on simple predictions of empirical content, in a framework of segmented housing markets, different income groups, and mobility.

The model assumes that there are two types of individuals: type $U$ individuals, who possess fewer labor market skills ${ }^{4}$ and generally earn lower wages, and the more skilled type $S$ individuals. Individuals are identical within a type. Both types of individuals decide whether to locate in city $M$ or elsewhere in the country. If unskilled individuals decide to move into $M$, they receive a wage $W_{M}^{U}$ that is a function of the measure of unskilled individuals in the city $\left(N_{U}\right)$, with $d W_{M}^{U}\left(N_{U}\right) / d N_{U}<0$. Skilled individuals receive a fixed wage $W_{M}^{S}$ (including skill-specific amenities) if they move into the city. ${ }^{5}$

Once they move into $M$, both unskilled and skilled individuals occupy a single dwelling. This implies that total population is equal to the housing supply. There is a continuum of dwelling qualities $(Q)$. There is a short-run supply of housing units of each quality. The supply function is represented by $S(p(Q), Q)$, with support $[0, \bar{Q}] ; P(Q)$ is the rent paid for a dwelling of quality $Q$. Tastes for quality differ between skilled and unskilled persons and can be represented by an increasing and strictly concave function $V^{n}(Q)$ for $n=U, S$. I normalize so that $V^{n}(0)=0$. I assume that $d V^{S}(Q) / d Q>d V^{U}(Q) / d Q \forall Q$, so skilled persons are always willing to pay more for a dwelling of the same quality. The utility function for both skilled and

\footnotetext{
4 The skill assignment process is exogenous to this analysis. Productive skills are understood in a comprehensive sense and include cognitive skills, education, training, experience, cultural knowledge, language, linguistic registers, social skills, social networks, and any other form of specific and general human capital. Many recent immigrants will start in their new countries with relatively low levels of such skills even if their formal academic qualifications are high. See Weiss (2000) for an account of the experiences of highly educated Russian immigrants in Israel.

5 Topel (1986) finds that "consistent with the greater geographic mobility of more educated workers, their wages are less sensitive to both current and future changes in relative local employment."
} 
unskilled is quasi-linear and separable in dwelling quality and a numeraire good. Both types of individuals enjoy a general amenity premium of $A_{M}$ for living in location $M$. Assuming that any prospective immigration shock is completely unexpected, the spatial equilibrium before the immigration shock for the unskilled individuals implies that

$$
V^{U}(Q)+A_{M}+W_{M}^{U}\left(N_{U}\right)-P(Q)=\overline{U_{U}}
$$

for all $Q$ (where $\overline{U_{U}}$ is equal to the utility level an unskilled worker can attain elsewhere in the country). Let $N_{U}^{*}$ be the number of unskilled individuals residing in $M$ in equilibrium.

From (1) I obtain the unskilled individuals' bid rents for quality $\left(\psi^{U}\right)$ and, similarly, for skilled individuals $\left(\psi^{S}\right):^{6}$

$$
\begin{aligned}
& \psi^{U}(Q)=V^{U}(Q)+A_{M}+W_{M}^{U}\left(N_{U}^{*}\right)-\overline{U_{U}}, \\
& \psi^{S}(Q)=V^{S}(Q)+A_{M}+W_{M}^{S}-\overline{U_{S}} .
\end{aligned}
$$

The cutoff quality level that separates the qualities occupied by unskilled and skilled individuals is $Q^{*}$. This magnitude corresponds to the intersection of the two groups' bid rents, where

$$
\begin{aligned}
& V^{S}\left(Q^{*}\right)+A_{M}+W_{M}^{S}-\overline{U_{S}} \\
& \quad=V^{U}\left(Q^{*}\right)+A_{M}+W_{M}^{U}\left(N_{U}^{*}\right)-\overline{U_{U}} .
\end{aligned}
$$

For qualities below $Q^{*}$ the market rent of the dwelling is determined by the unskilled bid-rent curve. For qualities above $Q^{*}$ rents are determined by the skilled bid-rent curve. Formally,

$$
P(Q)=\left\{\begin{array}{lll}
\psi^{U} & \text { if } & Q \leq Q^{*} \\
\psi^{S} & \text { if } & Q>Q^{*}
\end{array}\right.
$$

Thus, rents reflect both the specific advantages of the city and the competition between and within the groups for better locations. The model produces a segmented housing market. Each skill level occupies a different portion of the quality continuum.

Equation (4) and the housing market clearing condition (5) determine the measure of unskilled persons living at $M$ and the quality cutoff point ${ }^{7}$

$$
N_{U}^{*}=\int_{0}^{Q^{*}} S\left(\psi^{U}(Q), Q\right) d Q .
$$

This spatial equilibrium is portrayed in figure 1. The rent gradient corresponds to the highest bid rent at each quality.

\footnotetext{
${ }^{6}$ Notice that the bid rents and the final equilibrium prices of the dwellings capitalize the value of the local advantages in $M$. This is essential to the analysis.

${ }^{7}$ The number of skilled individuals in equilibrium can be obtained from the housing supply for those qualities above $Q^{*}$. Notice how the prices within this range are determined by the exogenous parameters.
}

Figure 1.-Equilibrium in the Housing Market

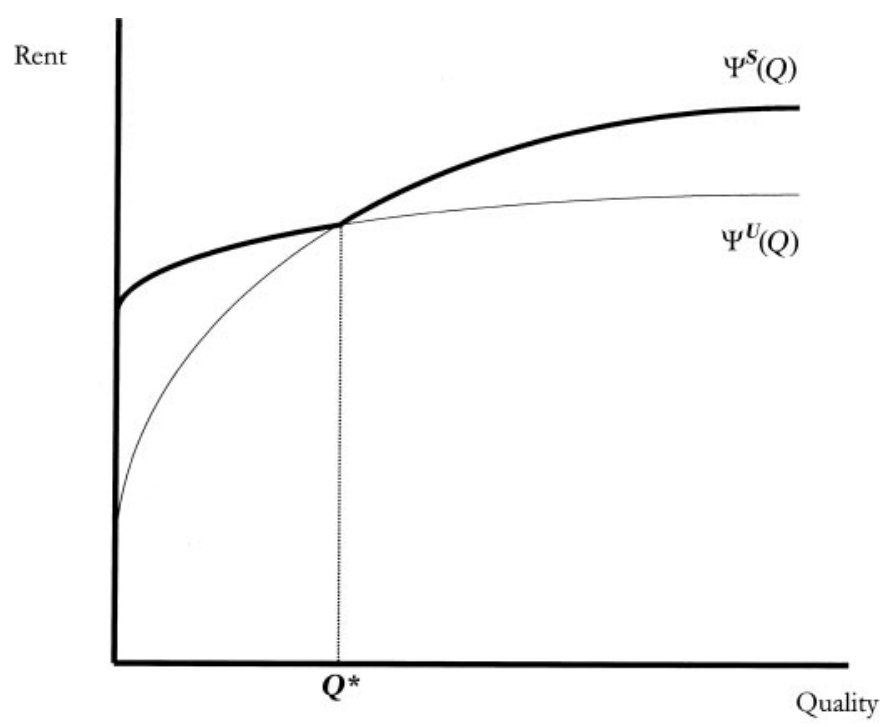

The figure shows the bid rents for quality for the unskilled and the skilled group $\left[\Psi^{U}(Q)\right.$ and $\Psi^{S}(Q)$ respectively]. The actual market rent corresponds to the highest bid rent at any given quality level: the envelope of the two bid rents (thicker line in the figure). Quality $Q^{*}$ separates the housing units occupied by the unskilled and skilled workers.

The nature of the equilibrium is determined by the advantage of the city for the skilled persons. ${ }^{8}$

Now, assume that an unpredicted immigration shock of immigrants with measure $N_{I}$ arrives in $M$ (with $N_{I}<N_{U}^{*}$ ). Assume that all of the immigrants are unskilled and have the same utility function as local unskilled individuals, but with the addition of a premium specific to $M$, namely $A_{I, M} \cdot{ }^{9}$ The short run will be characterized by moving costs that are arbitrarily high for the previous native city dwellers (Borjas, 2001). Thus, the new total measure of unskilled persons in the city is $N_{I}+N_{U}^{*}$. The number of skilled persons does not change. The slopes of the bid curves for both groups are determined by the preferences for quality and do not change because of the shock. Thus, the new equilibrium bid-rent curves can be characterized by adding a constant to the old ones (see Appendix A). Let $C_{U}$ and $C_{S}$ be these constants for the unskilled and skilled groups, respectively. Let $Q^{* *}$ be the new quality cutoff point that separates the skilled from the unskilled after the immigration shock.

Proposition $1 C_{U}>C_{S}>0$. In the short run, the increase in the rent paid by unskilled individuals is greater than the increase in the rent paid by skilled individuals.

\footnotetext{
${ }^{8}$ In Appendix 1 I provide some comparative statics of the model. Concretely, an increase in $W_{M}^{S}$ increases all housing rents and the supply of housing and population while reducing the quality cutoff point $Q^{*}$.

${ }^{9}$ This premium arises because city $M$ is used as a focal point to coordinate immigrants: they can invest in specific ethnic local public goods, and they value the proximity of individuals of the same nationa group. The premium is necessary in the model if we assume that immigrants have a preference for the city and do not spread all over the rest of the urban system.
} 
Proposition $2 Q^{* *}>Q^{*}$. In the short run, the quality cutoff point rises as a result of the shock: unskilled persons displace skilled ones from dwellings that are in the neighborhood of $Q^{*}$.

The proofs are given in the Appendix.

Proposition 1 is the main result of the model. If the housing market is segmented, an unskilled immigration shock has a greater impact on the rents paid by unskilled persons in the short run. This result holds even if the housing stock is formed by a continuum of qualities and persons can move upscale to avoid crowding in the lower qualities. An unskilled immigration shock may represent a major increase in the number of the unskilled. If the range of qualities occupied by the unskilled is small, it will take major price increases in these quality ranges to increase supply and to displace some of the skilled from "fringe" qualities (around $Q^{*}$ ). Figure 2 and Appendix A are helpful for understanding these relationships. This result contrasts with the general effects of population growth on housing rents with a homogeneous population in urban economics models (Brueckner, 1988).

A corollary to proposition 1 , for any model that considers attributes of housing other than quality (for instance, the share of people of a particular ethnicity or national origin in a neighborhood) and that assumes heterogeneous preferences for these attributes, is that an immigration flow that is small in comparison with the total population (that is, with the initial stock of housing) can have a substantial impact on rents in the market segments where immigrants concentrate.

The second important point of this simple model is that the long-run impact on rents needn't be equivalent to the short-run impact. Mobility and the existence of alternative locations become very relevant. In fact, under the assumptions of the model, the new long-run equilibrium (where I assume that moving costs are negligible) looks exactly like the initial equilibrium as long as $N_{I}<N_{U}^{*}$ : rents and wages do not change in the long run. If the marginal unskilled person is a native, he should be indifferent between any two locations, as in the initial equilibrium. This long-run equilibrium is achieved through the out-migration of native unskilled persons.

The results from previous empirical literature suggest that the sensitivity of the wages of the unskilled to incoming immigration [this is $W_{M}^{U}\left(N_{U}^{*}\right)-W_{M}^{U}\left(N_{U}^{*}+N_{I}\right)$ in the model] is very small. Thus, most of the short-run impact of immigration on unskilled previous residents comes, in the model, from changes in the prices of the dwellings that immigrants tend to occupy. Moreover, if wages are sticky, the dynamics toward the long-run equilibrium can, in theory, be entirely explained by short-run changes in housing rents.

\section{Data}

The main data source consists of observations from rental units in the 1974-1983 national and standard metropolitan
Figure 2.-Short-Run Equilibrium In the Housing Market with IMMIGRATION SHOCK

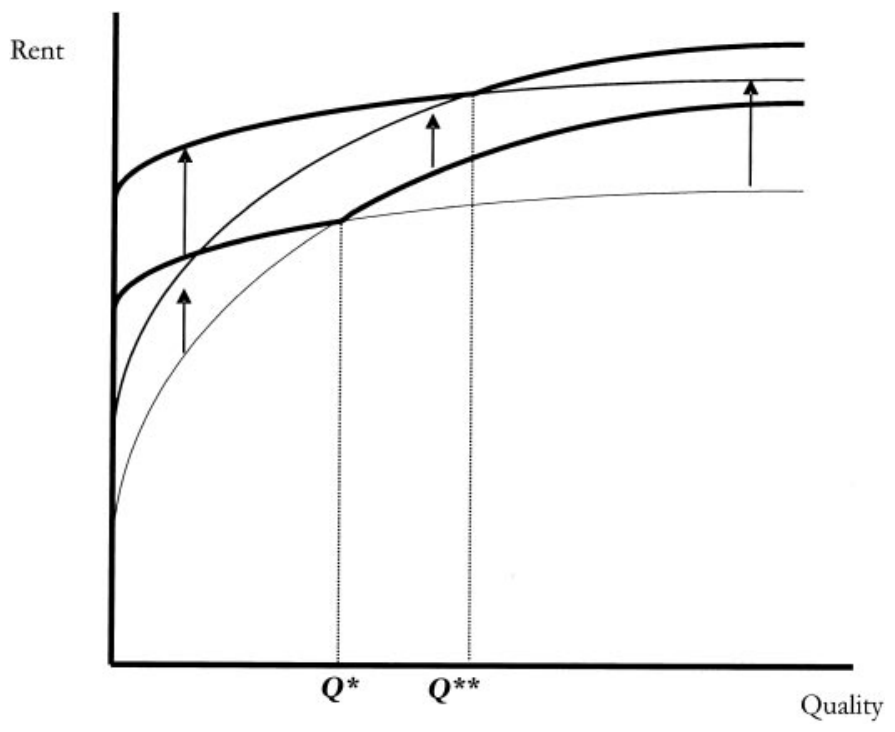

The figure shows how the bid rents change in the short run after an unskilled immigration shock. The bid rents shift upwards. $Q^{*}$ is the initial quality that separated the unskilled and skilled before the shock. bid rents shift upwards. $Q^{*}$ is the initial q
$Q^{* *}$ is the new separating quality level.

statistical area (SMSA) Annual Housing Survey (AHS). The national AHS sample surveyed some 60,000 housing units annually between October and December. Typically, $40 \%$ were rental units. Housing units were selected from the decennial Census of Population and Housing to be representative of the overall U.S. housing stock. The separate SMSA sample surveyed units in selected metropolitan areas, covering some 4,500 units in each SMSA until 1983, when the sample size was reduced by about $20 \%$. The metropolitan areas were selected on a four-year rotating basis. The Miami SMSA is included in the AHS metropolitan sample in 1979 and 1983, which provides a good portrait of the evolution of the Miami housing market before and after the boatlift. ${ }^{10}$ For other years I use the smaller Miami sample from the national AHS. Unfortunately, the other metropolitan areas covered by both the 1979 and 1983 metropolitan AHS do not make good comparison groups. Thus, the comparison cities are from the national sample. Typically, there are only a small number of complete observations on rents by MSA in the national sample, ${ }^{11}$ so I pool observations from several cities to generate comparison groups. The main comparison group is formed by the remaining Florida SMSAs included in the national AHS (encompassing Fort Lauderdale, West Palm Beach-Boca Raton, Tampa-Saint Petersburg, Orlando, and Jacksonville). As the second comparison group I use a group of cities with similar previous rent growth. The last comparison group is formed by the rest of the metropolitan areas identified in the national AHS.

${ }^{10}$ The SMSA sample for Miami provides observations for 4,000 units (about 1,600 rentals). Table 1 offers summary statistics of the data.

${ }^{11}$ The median number of observations with rent data by MSA is 45 . 
Table 1.-Weighted AHS Rentals Sample Means

\begin{tabular}{|c|c|c|c|c|c|c|c|c|}
\hline & \multicolumn{8}{|c|}{ Annual Housing Survey Samples } \\
\hline & \multicolumn{2}{|c|}{ Miami } & \multicolumn{2}{|c|}{ Metro Florida } & \multicolumn{2}{|c|}{ Similar Growth } & \multicolumn{2}{|c|}{ Metro U.S. } \\
\hline & 1979 & 1983 & 1979 & 1983 & 1979 & 1983 & 1979 & 1983 \\
\hline Nominal rent & $234.381(3.028)$ & $354.611(4.588)$ & $208.919(7.257)$ & $308.360(8.542)$ & $188.664(3.551)$ & $271.544(5.322)$ & $216.428(1.045)$ & $317.196(1.688)$ \\
\hline $\begin{array}{l}\text { Lives in central } \\
\text { city }\end{array}$ & $0.314(0.011)$ & $0.297(0.012)$ & $0.174(0.023)$ & $0.151(0.023)$ & $0.378(0.022)$ & $0.355(0.025)$ & $0.441(0.005)$ & $0.418(0.005)$ \\
\hline Lives in suburbs & $0.686(0.011)$ & $0.703(0.012)$ & $0.185(0.023)$ & $0.205(0.023)$ & $0.382(0.022)$ & $0.351(0.025)$ & $0.357(0.005)$ & $0.365(0.005)$ \\
\hline $\begin{array}{l}\text { Central city status } \\
\text { unknown }\end{array}$ & $0.000(0.000)$ & $0.000(0.012)$ & $0.641(0.029)$ & $0.644(0.027)$ & $0.240(0.019)$ & $0.294(0.020)$ & $0.202(0.004)$ & $0.217(0.004)$ \\
\hline 1 bedroom & $0.468(0.012)$ & $0.434(0.013)$ & $0.389(0.030)$ & $0.348(0.027)$ & $0.316(0.021)$ & $0.301(0.020)$ & $0.362(0.005)$ & $0.352(0.005)$ \\
\hline 2 bedrooms & $0.331(0.011)$ & $0.346(0.012)$ & $0.368(0.029)$ & $0.421(0.028)$ & $0.458(0.023)$ & $0.424(0.022)$ & $0.406(0.005)$ & $0.405(0.005)$ \\
\hline 3 bedrooms & $0.087(0.007)$ & $0.106(0.008)$ & $0.163(0.022)$ & $0.178(0.021)$ & $0.152(0.016)$ & $0.195(0.017)$ & $0.145(0.003)$ & $0.158(0.004)$ \\
\hline 4 bedrooms & $0.012(0.002)$ & $0.013(0.003)$ & $0.013(0.006)$ & $0.015(0.007)$ & $0.022(0.007)$ & $0.025(0.007)$ & $0.024(0.001)$ & $0.025(0.001)$ \\
\hline 5 bedrooms & $0.001(0.000)$ & $0.001(0.001)$ & $0.006(0.004)$ & $0.002(0.002)$ & $0.009(0.004)$ & $0.006(0.003)$ & $0.002(0.000)$ & $0.004(0.001)$ \\
\hline $\begin{array}{l}6 \text { or more } \\
\text { bedrooms }\end{array}$ & $0.000(0.000)$ & $0.001(0.001)$ & $0.000(0.000)$ & $0.000(0.000)$ & $0.000(0.000)$ & $0.000(0.000)$ & $0.000(0.000)$ & $0.000(0.000)$ \\
\hline Built before 1965 & $0.445(0.012)$ & $0.417(0.013)$ & $0.360(0.030)$ & $0.313(0.027)$ & $0.516(0.023)$ & $0.512(0.022)$ & $0.594(0.005)$ & $0.562(0.005)$ \\
\hline \multirow[t]{3}{*}{$\begin{array}{l}\text { Unweighted } \\
\text { number of } \\
\text { observations }\end{array}$} & 1915 & 1562 & 281 & 317 & 494 & 525 & 10863 & 11084 \\
\hline & & & \multicolumn{6}{|c|}{ Population-weighted Group Means (City-Wide Data) } \\
\hline & & & Miami & Metro & lorida & Similar Grov & & $\begin{array}{l}\text { Metro } \\
\text { U.S. }\end{array}$ \\
\hline \multicolumn{3}{|c|}{ Population growth (1974-1979) } & $1.451 \%$ & \multicolumn{2}{|c|}{$2.551 \%$} & \multicolumn{2}{|l|}{$1.282 \%$} & $0.868 \%$ \\
\hline \multicolumn{3}{|c|}{ Employment growth (1974-1979) } & $3.585 \%$ & \multicolumn{2}{|c|}{$4.887 \%$} & \multicolumn{2}{|l|}{$3.912 \%$} & $3.293 \%$ \\
\hline \multicolumn{3}{|c|}{ Income/capita growth (1974-1979) } & $8.202 \%$ & \multicolumn{2}{|c|}{$8.202 \%$} & \multicolumn{2}{|l|}{$8.914 \%$} & $8.993 \%$ \\
\hline \multicolumn{3}{|c|}{ Income/capita (1979) } & 9,492 & \multicolumn{2}{|c|}{9,340} & \multicolumn{2}{|l|}{9,476} & 9,944 \\
\hline \multicolumn{3}{|c|}{ Population (1979) } & $1,584,586$ & \multicolumn{2}{|c|}{$1,055,418$} & \multicolumn{2}{|l|}{$1,271,773$} & $2,755,306$ \\
\hline
\end{tabular}

All micro-sample means stand for weighted sample proportions, with the exception of nominal rent. Data for Miami from AHS SMSA samples. Data for Florida, similar previous growth group, and United States from the AHS national sample. Other Florida data include observations from the following MSAs: Fort Lauderdale, Jacksonville, Orlando, Tampa-St. Petersburg, West Palm Beach-Boca Raton. The similar growth group includes West Palm Beach, Tucson, South Bend, Appleton, Rochester, Atlanta, Tampa, Milwaukee, Spokane, and Greensboro. The national metro sample includes all metropolitan areas identified by the AHS. Standard errors for the estimated means (not sample standard errors) in parentheses. "One bedroom" includes studios. Population-weighted group means use data from the Bureau of Economic Analysis on MSA-level employment, income, and population. Income per capita growth in current dollars.

The AHS followed the same units from 1974 to 1983 , with additions of new housing and deletions because of demolition and nonresponses. Therefore, this data set allows for a longitudinal treatment. The AHS was not carried out in 1982. After 1983 the national sample reduced its periodicity to two years, starting with the 1985 sample. The sample of units changed, and it is not possible to match the 1979 units with the observations from the 1985 sample.

Data on the characteristics of Miami's residents and Florida's residents are also extracted from the U.S. 1980 and 1990 Census Public Microdata Samples (IPUMS).

Fair market rent (FMR) data are from the Department of Housing and Urban Development (HUD). An individual's housing rent must be below the corresponding FMR in the metropolitan statistical area (MSA) in order to be eligible for housing subsidies from the federal government. The FMR corresponds to the price of a vacant 2-bedroom rental unit at the 45th percentile of the MSA's distribution. It is calculated annually by HUD using data from the AHS SMSA samples, when available, combined with random samples. The FMR can be interpreted as the price for a rental unit of moderate quality. The Bureau of Labor Statistics provides the urban consumer price index (CPI) that I use to deflate rents (the base is an average of prices over the 1982-1984 period).

Data on the postal codes of legal immigrants' intended residences are from the "Immigrants Admitted to the United States, 1990" files, from the Immigration and Naturalization Service. The data have several caveats worth mentioning. First, this data source does not include the population of illegal immigrants. Second, many foreign-born persons are admitted into the United States some years after they have arrived in the country as nonimmigrants. Finally, the intended residence reported by immigrants may not end up being their final destination. These data nevertheless have their advantages over decennial census data. They are a reasonable indicator of recent legal immigration flows. Census data only allow us to determine the decennial change in the foreign-born population, and the number of immigrants that are present in the city and that arrived in the city within the last 5 years (for a rather restricted sample of MSAs). There is a very strong correlation between the change in the foreign-born by city in the decennial censuses 
TABle 2.-Immigrants and Fair Market Rents

\begin{tabular}{|c|c|c|c|c|c|}
\hline & \multicolumn{2}{|c|}{$\log ($ Rent91) } & \multicolumn{2}{|c|}{$\log (\operatorname{Rent} 92)-\log (\operatorname{Rent} 90)$} & \multirow{2}{*}{$\begin{array}{c}\text { Sample Means } \\
\text { (5) }\end{array}$} \\
\hline & (1) & (2) & (3) & (4) & \\
\hline $\log ($ income per capita) & $0.536^{* *}(0.048)$ & $0.538 * *(0.048)$ & & & $9.808(0.184)$ \\
\hline New immigrants per 100 population (1990) & $0.144 * *(0.035)$ & $0.144 * *(0.035)$ & $0.024 * *(0.005)$ & $0.023^{* *}(0.005)$ & $0.172(0.217)$ \\
\hline Housing unit permits per capita (1989) & & $-0.372 \quad(1.603)$ & & $-0.114 \quad(0.499)$ & $0.005(0.005)$ \\
\hline $\log ($ population90) $-\log ($ population89) & & & $0.019 \quad(0.074)$ & $0.139 \quad(0.124)$ & $0.012(0.016)$ \\
\hline State fixed effects & Yes & Yes & No & No & \\
\hline$R$-square & 0.847 & 0.827 & 0.088 & 0.092 & \\
\hline$N$ & 309 & 309 & 309 & 309 & 309 \\
\hline
\end{tabular}

to provide a characterization of the sample observations. They should not be used to make inferences about the U.S. population. Sample standard errors in parentheses.

and the cumulative number of legal immigrants admitted over a similar period. ${ }^{12}$ Finally, the data report the first time that the immigrants entered the United States as nonimmigrants: for example, in 1990 about $70 \%$ of admitted immigrants entered the country the same year in which they were admitted. About $90 \%$ of the immigrants admitted in 1990 report having arrived in the United States in or after 1988.

Postal codes from the "Immigrants Admitted to the United States, 1990" files are matched to 1990 statistical metropolitan areas using the Census MABLE geocorrelation engine. Data on the evolution of per capita area income, employment, and population at the MSA level are obtained from the Bureau of Economic Analysis and the Census Bureau.

Data on the Mariel boatlift population are obtained from a sample of 514 refugees (Mariel Cubans in Miami, 19831986; Johns Hopkins University) gathered by Alejandro Portes. Portes randomly sampled households in census tracts with a large share of Cuban immigrants in 1980.

The evolution of housing prices after 1982 is obtained from the Freddie Mac repeated-sales index. This index uses the consecutive transaction prices of a longitudinal sample of housing units. Data on authorized housing starts at the MSA level are from the Census Bureau's C40 series "New Privately Owned Housing Units Authorized."

\section{Background and Empirical Strategy}

Recent immigrants to the United States and other countries tend to occupy rental units of relatively low quality. ${ }^{13}$

\footnotetext{
${ }^{12}$ I run a regression of the cumulative number of immigrants into an MSA from 1980 to 1989 (I impute the values from 1980 to 1982 with 1983 values, the first year for which the INS provides information on the ZIP code of intended residence of immigrants). A regression of the change of the Census's foreign-born on the INS estimate of the cumulative number of new immigrants yields a coefficient of 1 ( $t$-statistic of 16), even after controlling for population in 1980 (a general scale effect).

13 Joint Center for Housing Studies (2000). Callis (1997) uses the CPS to estimate that in 1996 the home-ownership rate for a noncitizen who entered the United States in 1990 or later was only 14.7\%. Friedman,
}

Most immigrants arrive in their new country of residence without assets that can be used as collateral to buy a house. Some of them do not have credit records comparable to those in the United States. Many are uncertain as to the duration of their stay in their port of entry and are not willing to undertake the homeownership commitment. Furthermore, the supply of housing with the characteristics demanded by immigrants is not completely elastic in the short run.

There is a very small literature on the impact of immigration on the evolution of rental prices. Muller and Espenshade (1985) compared the evolution of prices from 1967 to 1983 in Los Angeles, a port of entry for a large number of immigrants, to changes in prices in the rest of the United States. They found that "prices for medical care, rental housing, private transportation, and fuel rose faster than prices nationwide, and the price of rental housing was noticeably higher." These authors explain this pattern by arguing that "because most immigrants live in rental units, the rental housing market would experience substantial pressure from the rising immigrant-induced demand." Burnley, Murphy, and Fagan (1997) found immigration to be one of the important correlates of changes in housing prices in Sidney, Australia. Ley and Tuchener (1999) reported a strong time-series correlation between housing prices and immigration in Toronto and Vancouver, Canada. These studies are descriptive in nature. The authors do not control for other variables that could account for changes in housing prices, such as economic cycles.

Although suggestive, previous results cannot establish the causal effect of immigration on rents. Many other social and economic changes were specific to the Los

Rosenbaum, and Schill (1998) find that foreign-born households in New York City are more likely to live in crowded and dilapidated housing units. The fact that immigrants disproportionately consume rental units of lower quality is also true in the European context. Thave (1999) reports that $78.75 \%$ of immigrant households in France dwelt in rental units in 1984. The average area of an immigrant dwelling was $63 \mathrm{~m}^{2}$, compared to $83 \mathrm{~m}^{2}$ for French nationals. 
Angeles, Sidney, Toronto, and Vancouver metropolitan areas that could have accounted for the changes in rents and housing prices and could be correlated with immigration.

The positive correlation between immigration and rental prices seems pervasive, nevertheless. The first column in Table 2 presents a reduced-form regression of the $\log$ of 1991 FMR in MSAs on other variables. In column (1) the explanatory variables are the log of MSA population, the log of MSA per capita income, and the number of new immigrants per 100 population in 1990. State fixed effects are included to control for broad regional effects. Immigration appears strongly associated with higher prices for apartments of moderate quality. It can be argued, though, that immigration is endogenous to and captures the effect of an omitted variable: expectations of future economic growth. ${ }^{14}$ To control for this, column (2) introduces the rate of new housing permits per capita in 1989 as an explanatory variable. Expectations of future growth should translate into greater building activity. The results do not change. Yet, immigration flows might be correlated with unobservable MSA amenities that attract immigrants and explain the higher rents. To address this concern, columns (3) and (4) repeat the exercise using differences in rents, income, and population between 1990 and 1992. The change of FMR between 1990 and 1992 seems strongly associated with the immigration inflow in 1990. An immigration inflow that represented $1 \%$ of the MSA initial population was associated with a $2.3 \%$ increase in rents two years later. This effect is found despite the fact that I am controlling for income and overall population growth. ${ }^{15}$

The results in Table 2 clearly point to immigration as one possible explanatory factor behind rent increases for housing of moderate quality. These results, though, might be biased. Immigration is endogenous to rental prices: at the margin, if rents become unusually high, some immigrants will decide to move toward less expensive locations. In principle, this could bias the estimates downward. At the same time, omitted variables (such as positive productivity shocks or changes in amenities that are valuable to firms, immigrants, and natives) could explain the changes in rental prices and be positively correlated with immigration flows. If the new-housing-permits variable does not capture this effect, the omitted variable problem would bias the estimates upward.

\footnotetext{
${ }^{14}$ Counter to that argument, note that expectations may change the asset price of housing units but should not directly change spot-market rents. If the population level is based on expectations, this could explain increasing rents; but the regressions already control for this variable.

${ }^{15}$ Notice that immigration can have an impact even if it is associated with no population growth. With a very inelastic short-term housing supply, we need higher rents in order to displace natives from the city that received the immigration inflow. Net population changes may be very small. Finding an effect of immigration even when we control for population growth suggests that immigration inflows are more exogenous to rent changes than are other population flows.
}

To assess the robustness of these findings and tackle the possible identification problem I make use of the exogenous immigration shock described by Card (1990). About 125,000 Cuban immigrants arrived in southern Florida between May and September 1980. The inflow responded to an exogenous and unpredicted decision by the Cuban government to allow emigration from that country. Of these 125,000 immigrants, Card estimates that about 50\% (some 62,500 people, or $3.8 \%$ with respect to Miami's 1980 population) decided to stay in the Miami metropolitan area. Portes and Stepick (1985) reckoned that as of 1983 only "one third of the Mariel refugees were resettled and remain outside the Miami SMSA." Thus, as of 1983, the number of Mariel immigrants in Miami had reached about 84,000 people (5.5\% of Miami's population in 1980). Mariel immigrants were relatively unskilled, in both formal education and fluency in English (see Portes \& Stepick, 1985). ${ }^{16}$

Table 3 supplies us with some data on the Miami rental market in April 1980. The market was clearly dominated by low-income tenants before the boatlift. Of tenants in rental units, $72 \%$ had household incomes below the Miami median. About $40 \%$ of the Miami population lived in rental units $(646,627$ people, from my tabulations of the 1980 Census). For immigrants living in the United States less than 5 years, the proportion of renters was a much higher $70 \%$. Indeed, most of the new Mariel immigrants were participants in the rental market by 1983. My tabulations from the "Mariel Cubans in Miami" sample show that $92 \%$ of Mariel Cubans lived in rental housing (compared to $52.42 \%$ for the population living in the census tracts sampled by this study, according to the 1980 Census). Using Card's (1990) conservative estimate, the number of new immigrants thus represented an exogenous increase of about 9\% in the renters' population. If we use Portes and Stepick's (1985) estimates, the boatlift could have increased the initial renters' population by $12 \%$.

To estimate the impact of such a shock on rental prices, I compare the evolution of rents in Miami with that of rents in other cities before and after the shock. The identifying assumption is that nothing else specific to Miami accounts for any diverging trend in rental prices. The basic differencesin-differences equation that I estimate is

$$
R_{i t}=\alpha_{i}+\beta D_{\text {after }}+\gamma D_{\text {after }} D_{\text {Miami }}+\varepsilon_{i t} \text {, }
$$

where $R_{i t}$ is the rent (or log rent) for unit $i$ at year $t, \alpha_{i}$ is a unit fixed effect, $D_{\text {after }}$ and $D_{\text {Miami }}$ are dummy variables that take value 1 if $t>1980$ and if the MSA is Miami, respectively, and $\varepsilon_{i t}$ is an error term.

It is not possible to find a perfect "twin" comparison city for Miami. Rent levels in Miami were bound to be different from those in other cities because of different amenities and

\footnotetext{
${ }^{16}$ Portes and Stepick (1985) argue that only $24.8 \%$ of the Mariel entrants had a high school degree, and only $10.6 \%$ reported speaking English well or very well.
} 
Table 3.-The Rental Market in Miami (1980)

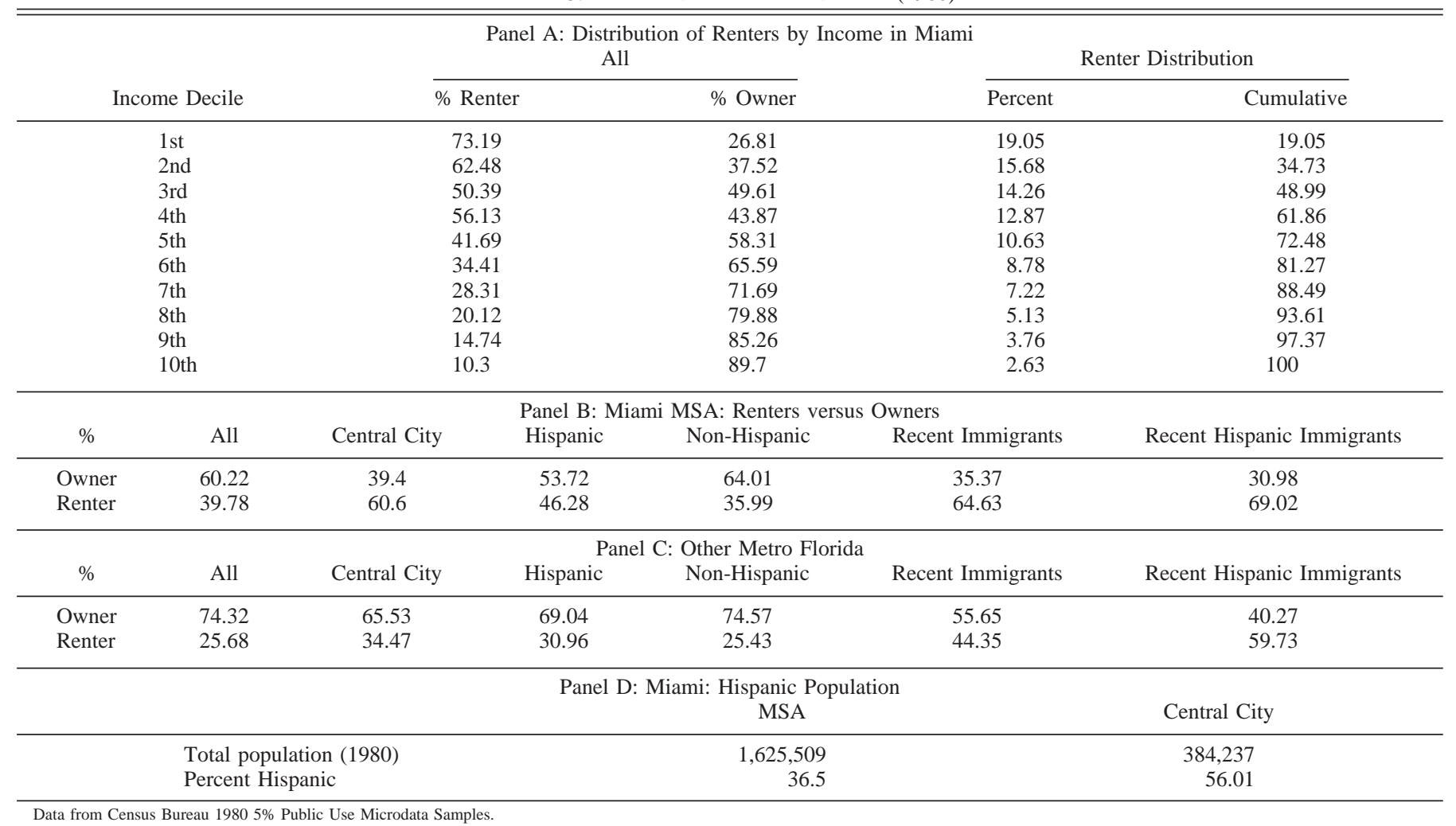

labor markets. The approach in this paper is to construct three different comparison groups that are plausible a priori, to compare the performance of the housing markets and other economic variables prior to the boatlift, checking for previous trends, and to assess the robustness of the findings to the use of plausible alternative groups.

Geography is the most important determinant of rents and housing prices. State dummies explained about $63 \%$ of the variance of MSA median rent levels in 1990, and 68\% of the variance of the change in median rents between 1980 and 1990. ${ }^{17}$ Thus, the first of my comparison groups is the rest of the metropolitan areas in Florida that are included in the 1979 and 1983 Annual Housing Surveys: Fort Lauderdale, Jacksonville, Orlando, Tampa-St. Petersburg, and West Palm Beach-Boca Raton.

The second comparison group is based on selecting several metropolitan areas that replicate Miami's evolution of rents before 1979. In particular, I calculate the evolution of median rents in the national AHS by metropolitan area from 1975 to 1979. The similar-previous-growth comparison group is formed by ten metropolitan areas ${ }^{18}$ with the closest median growth rate to Miami in that period: West Palm Beach (FL), Tucson (AZ), South Bend (IN), Appleton

\footnotetext{
17 The results reflect the $R$-square of the following two regressions: 1990 Census median rent by MSA on state dummies; difference of the log of median rents by MSA between 1980 and 1990 on state dummies. There are 325 MSA observations and 51 states.

${ }^{18}$ The results are not sensitive to reasonable changes in the number of comparison cities.
}

(WI), Rochester (NY), Atlanta (GA), Tampa (FL), Milwaukee (WI), Spokane (WA), and Greensboro-Winston-Salem (NC). Note that two of the comparison cities are also in the comparison group in Card (1990). ${ }^{19}$

The third comparison group encompasses all of the U.S. metropolitan areas identified in the AHS. The group is intended to capture broad national trends in housing markets and economic conditions, dispel potential concerns over preselection bias, and provide a further check on the robustness of the findings. As still further checks, I will also note that the results are very robust to the use of two other plausible broad regional comparison groups: the SouthAtlantic Division and South Region from the Census, both containing Florida. Figure 3 provides a picture of all these groups.

Table 1 summarizes the previous evolution of other key economic variables with available periodic data prior to the boatlift: employment, population, and income per capita. Remarkably, the similar-previous-rent-growth group exhibited very close growth to Miami in population,

\footnotetext{
${ }^{19}$ Unfortunately, the two other cities, Houston and Los Angeles, do not make good comparison groups. Houston was experiencing a construction boom at the end of the 1970 s and early 1980s, driven by the contemporaneous increase in oil prices. In Los Angeles, the previous evolution of rents was very dissimilar from Miami's: during the previous 4-year period, 1975-1979, the growth of the CPI-deflated median rent in Los Angeles was $10.80 \%$, compared to $-9 \%$ in Miami; over that period, Los Angeles ranked 31st out of 111 metropolitan areas in rent growth, whereas Miami ranked 92nd.
} 
Figure 3.-The Comparison Groups
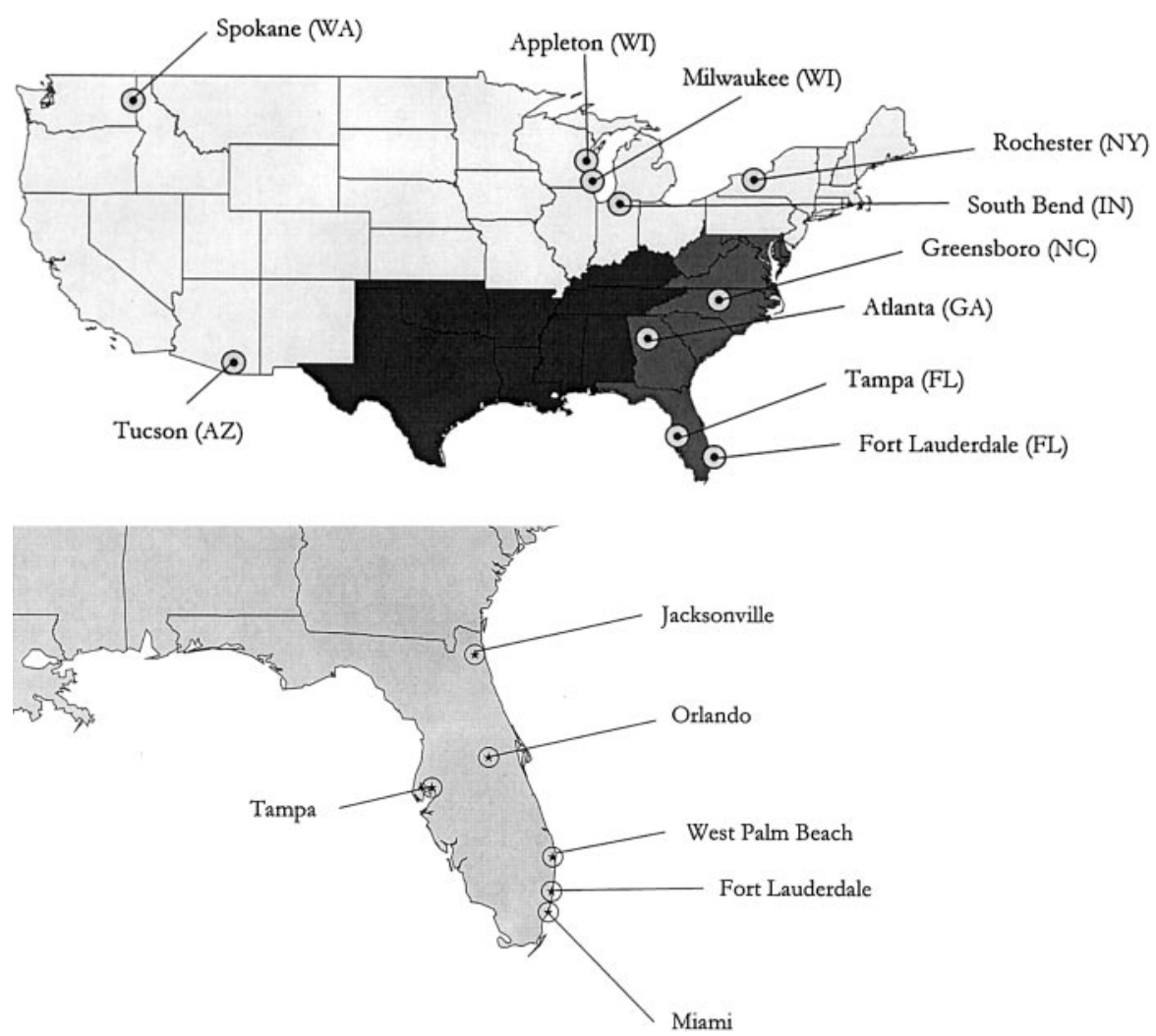

Upper map: The states in darker color represent the South census region excluding the South-Atlantic Division. The South-Atlantic Census Division States are in medium shade. The map displays the metropolitan areas in the similar-growth comparison group. Lower map: Miami and the Florida comparison cities in the annual housing surveys.

employment, and income per capita during 1974-1979, but the trends for the other two groups are not dissimilar. All in all, the three groups seem to provide reasonable counterfactuals with regard to previous trends in economic growth.

The housing markets in the three comparison groups chosen seem to provide good benchmarks. Figure 4 portrays the evolution of sample mean log rents in Miami and the comparison cities from 1974 through 1983, using the national AHS samples. Figure 5 shows the evolution of the differential between the groups. The evolution of rents for the Florida comparison group was similar to Miami's from 1974 to 1979 , and, obviously, so was that of the similargrowth comparison group. The comparative evolution for Florida is bumpier, but it is hardly possible to discern any previous upward or downward trend in the rental price differential.

There was a clear convergence in rents between Miami and the rest of the metropolitan United States before 1977. From 1977 to 1979 the differential seems to have stabilized. The graph seems to preclude the possibility that the estimates capture the effect of previous upward trends in the Miami rent differential and introduces a somewhat conservative bias into the quantification of an increase due to the Mariel boatlift when using the U.S. comparison group.
In all cases the rent differential increased sharply in 1981, right after the boatlift. As Figure 4 indicates, the differential was driven by a sharp increase in rents in Miami in 1981. In fact, Miami's real rents had been very stable during 19761980. The evidence is consistent with an impact from the Mariel boatlift. Previous trends in the evolution of rents could not account for the increase in the differential; most of the differential arose from a sharp increase in rents in Miami after the boatlift. The pictures, of course, cannot be taken as proof of the impact of the boatlift on rentals: the sample composition may vary somewhat between SMSAs, and the different qualities of the units could explain the price movements (due to composition effects).

The regression approach will better control for the composition of housing units in the samples and will allow us to determine the quantitative impact and statistical significance of the boatlift. I will also show other results consistent with the immigration shock.

\section{Results and Discussion}

\section{A. The Price Response}

To quantify the impact statistically, the paper resorts to a differences-in-differences regression. I start by matching the 
Figure 4.-Rents in Miami and Comparison Cities (1974-1983): LEVELS
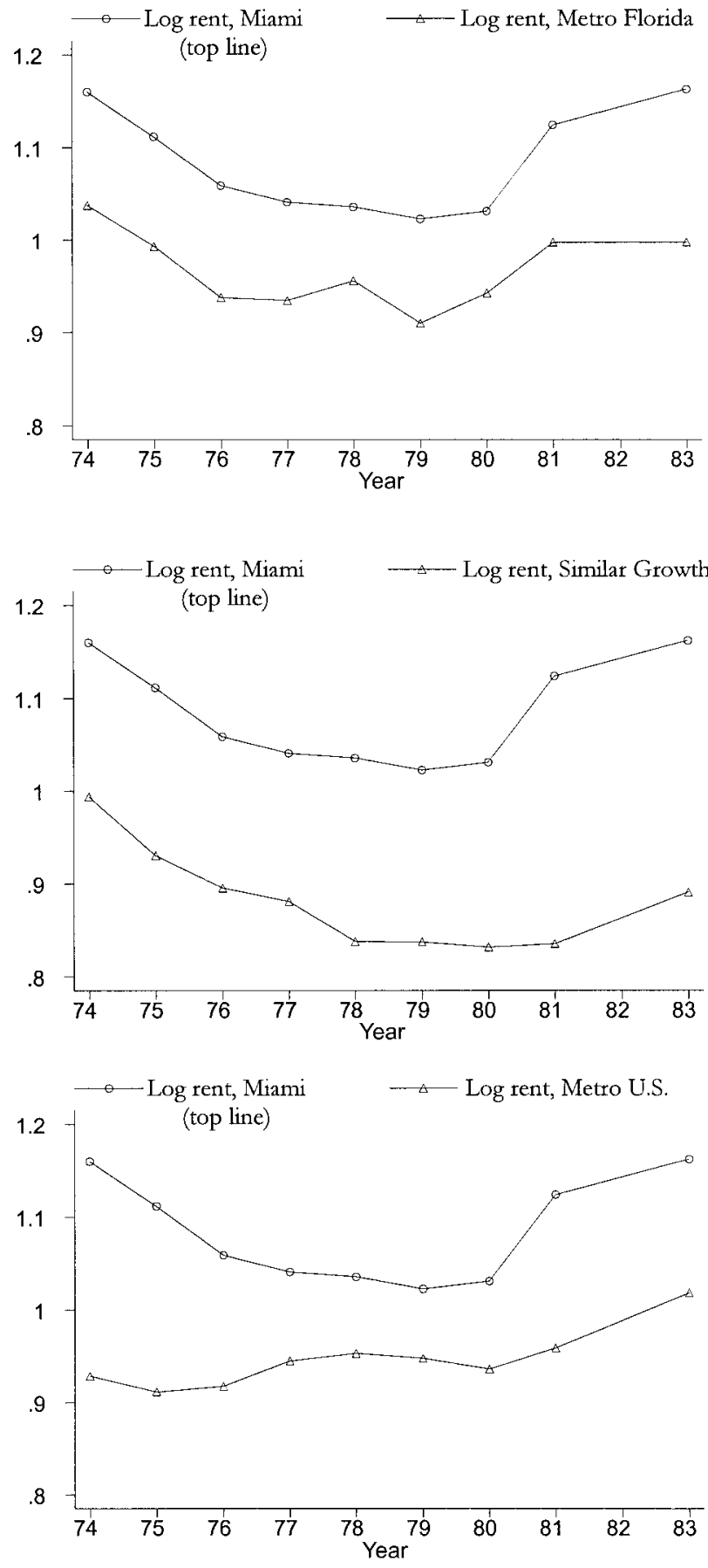

rental units that appear in the 1979 and 1983 samples. ${ }^{20}$ The differences-in-differences estimates include a unit fixed ef-

${ }^{20}$ The results are robust to controlling for possible attrition bias. For instance, it may be that the units retired from the market tend to be the units with lower rent growth, and it may conceivably have been easier to convert rental units into condos in the Miami area. To address this issue, I undertook the differences-in-differences regression with all observations, no unit fixed effects, and some controls for unit quality. The results (available upon request) are not very different but are more imprecise. A previous version of the paper also showed the results from Heckman-type
Figure 5.-Rents in Miami and Comparison Cities (1974-1983): DIFFERENCES
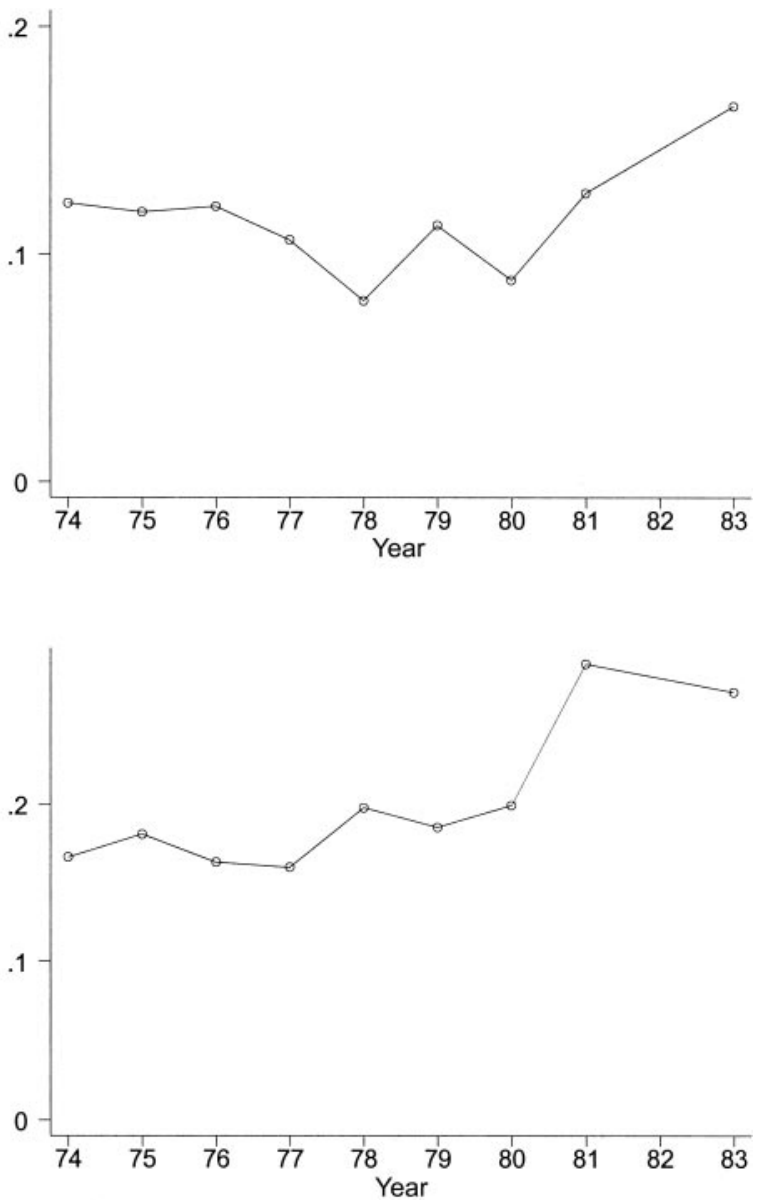

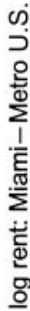

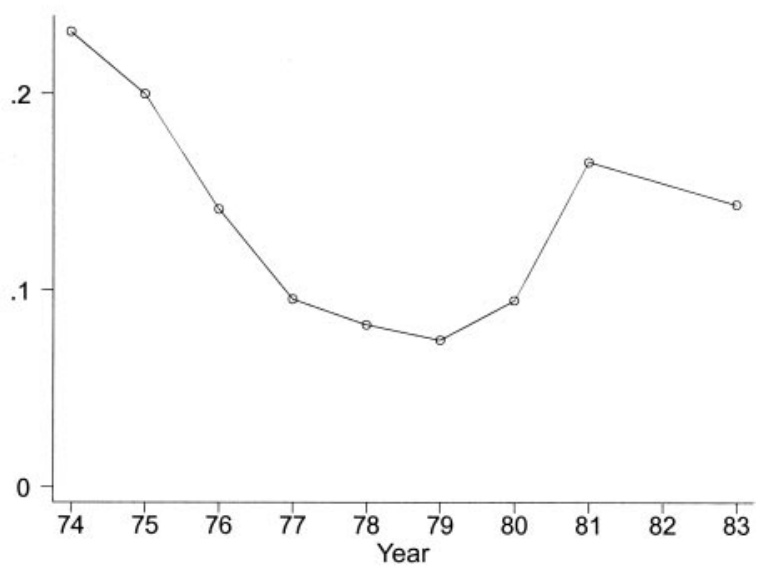

fect. Thus I control to a great extent for the unobserved quality (location and structure) of the dwellings in the sample. The regressions consider rents for rental units not in public housing projects.

selection adjustments using the U.S. comparison group (available on request): the results remained unchanged. 
TABLE 4.-DifFerences-IN-DiFferences: Miami vs. Comparison Groups

\begin{tabular}{|c|c|c|c|c|c|c|}
\hline & \multicolumn{4}{|c|}{ Panel A: 1979-1983 } & \multicolumn{2}{|c|}{ Metro U.S. } \\
\hline & $\begin{array}{l}(1) \\
\text { Rent }\end{array}$ & $\begin{array}{c}(2) \\
\log (\text { Rent })\end{array}$ & $\begin{array}{l}(3) \\
\text { Rent }\end{array}$ & \multirow{2}{*}{$\begin{array}{c}(4) \\
\log (\text { Rent }) \\
0.011^{* *}(0.014)\end{array}$} & \multirow{2}{*}{$\begin{array}{c}\text { (5) } \\
\text { Rent } \\
10.869 * *(0.767)\end{array}$} & \multirow{2}{*}{$\begin{array}{c}(6) \\
\log (\text { Rent }) \\
0.038^{* *}(0.004)\end{array}$} \\
\hline 1983 & $5.786 \quad(5.988)$ & $0.035 \quad(0.027)$ & $3.633 \quad(2.341)$ & & & \\
\hline Miami $\times 1983$ & $20.677 * *(6.382)$ & $0.071 * *(0.029)$ & $22.830 * *(3.217)$ & $0.095 * *(0.018)$ & $15.593 * *(2.336)$ & $0.068 * *(0.011)$ \\
\hline Constant & $212.929 * *(2.900)$ & $5.248 * *(0.013)$ & $200.314 * *(1.374)$ & $5.211 * *(0.008)$ & $217.586 * *(0.554)$ & $5.276 * *(0.003)$ \\
\hline Unit fixed effects & Yes** & Yes** & Yes** & Yes** & Yes** & Yes** \\
\hline \multirow{4}{*}{$\begin{array}{l}R \text {-square } \\
N \times T\end{array}$} & 0.857 & 0.8597 & 0.904 & 0.895 & 0.9104 & 0.8744 \\
\hline & 2810 & 2810 & 3114 & 3114 & 18518 & 18518 \\
\hline & \multicolumn{2}{|c|}{ Metro Florida } & \multicolumn{2}{|c|}{$\begin{array}{l}\text { Panel B: } 1979-1981 \\
\text { Similar Previous Growth }\end{array}$} & \multicolumn{2}{|c|}{ Metro U.S. } \\
\hline & $\begin{array}{l}(1) \\
\text { Rent }\end{array}$ & $\begin{array}{c}(2) \\
\log (\text { Rent })\end{array}$ & $\begin{array}{l}(3) \\
\text { Rent }\end{array}$ & $\begin{array}{c}(4) \\
\log (\text { Rent })\end{array}$ & $\begin{array}{l}(5) \\
\text { Rent }\end{array}$ & $\begin{array}{c}(6) \\
\log (\text { Rent })\end{array}$ \\
\hline 1981 & $-2.616(6.109)$ & $0.010(0.026)$ & $-3.827(2.604)$ & $-0.024(0.014)$ & $-3.588 * *(0.675)$ & $-0.021 * *(0.003)$ \\
\hline Miami × 1981 & $26.131 * *(7.824)$ & $0.081 * *(0.033)$ & $27.343^{* * *}(5.536)$ & $0.114 * *(0.025)$ & $27.206^{* *}(4.924)$ & $0.112 * *(0.021)$ \\
\hline Constant & $212.894 * *(2.973)$ & $5.262 * *(0.012)$ & $199.146 * *(1.704)$ & $5.202 * *(0.009)$ & $216.898 * *(0.481)$ & $5.270 * *(0.002)$ \\
\hline Unit fixed effects & Yes** & Yes** & Yes** & Yes** & Yes** & Yes** \\
\hline$R$-square & 0.849 & 0.871 & 0.908 & 0.913 & 0.908 & 0.899 \\
\hline$N \times T$ & 752 & 752 & 1076 & 1076 & 17388 & 17388 \\
\hline
\end{tabular}

Standard errors in parentheses. Sample weights used in all regressions. In all tables, $* *$ denotes a coefficient significant at the $5 \%$ level, * denotes a coefficient significant at the $10 \%$ level. The regressions include housing units with observations in both the 1979 and 1983 samples. The Florida comparison group encompasses the following metropolitan areas in the national sample of the Annual Housing Surveys (1979 and 1983): Jacksonville, Fort Lauderdale, Orlando, Tampa, Saint Petersburg-Clearwater, and West Palm Beach-Boca Raton. The similar-previous-growth group is constructed by selecting the 10 metropolitan areas with the clost (GA), Tampa (FL), Milwaukee (WI), Spokane (WA), and Greensboro-Winston-Salem-High Point (NC). The metro U.S. group includes all observations from the National AHS in identified metropolitan areas.

Panel A in Table 4 shows the results of this fixed-effects approach. I deflate rents in 1983 to their real value in 1979 dollars. ${ }^{21}$ The advantage of the $1979-1983$ time frame is that I can use observations from the SMSA AHS sample for Miami and estimate the changes in rents in Miami with more precision. I use the national AHS sample for the comparison groups, for which I pool observations from the different comparison MSAs. The first column uses real rents as the dependent variable; the second column uses the logarithm of real rents. The quantitative conclusion is clear: there was a differential increase in rental prices in Miami from 1979 to 1983 with respect to the comparison groups. Columns 3 to 6 show that the choice of the comparison group does not affect this conclusion. The higher rental price differential in Miami appears to be specific to that MSA. To interpret the results as differential percentage

\footnotetext{
${ }^{21}$ The increase in the U.S. urban CPI between December 1979 and December 1983 is used to deflate 1983 rents into 1979 dollars. Although the CPI takes into account changes in housing prices, the fact that we are dividing all of the 1983 observations by the same factor rules out any endogeneity bias. Moreover, the evolution of the general urban CPI and the urban CPI net of shelter is identical in this period (the increase in the former representing $98.14 \%$ of the increase in the latter). The Miami 1983 difference results in the log specification are unchanged by this transformation. The differences-in-differences results in levels are only divided by the inflation factor. The estimation in real terms is interesting, because it yields the change in the prices in terms of the opportunity cost of a 1979 dollar spent on an alternative bundle of goods, including housing, in a hypothetical U.S. urban market. The cumulative urban CPI inflation rate between December 1979 and December 1983 was 32\%.
}

changes, I use the logarithmic specification and the approximation to percentages supplied by Kennedy (1981). The estimated boatlift impact represents a differential rent hike of $7.31 \%, 9.99 \%$, and $7.02 \%$ when the comparison groups are Florida, the similar-previous-growth group, and the rest of the metropolitan United States, respectively. ${ }^{22}$

Further evidence about the coincidence of the boatlift with the rent hike in Miami is supplied in Panel B of Table 4. The table presents the fixed effects regressions for the AHS national subsamples. ${ }^{23}$ Here I examine the price differential between 1979 and 1981. Because the data were collected from October to December, the comparison gives us a good picture of rentals right before the boatlift, while leaving some time for annual contracts to be renegotiated afterward. If the rent differential in 1983 was actually due to

22 The results are only slightly smaller and always statistically significant with alternative broad regional groups: $6.3 \%$ using cities in the Southern Census Region as a comparison group, and 5\% using the South-Atlantic Census Division.

${ }^{23}$ Appendix B, Table B1 addresses the comparability between the smaller national and the bigger SMSA samples of the AHS. Notice that I am confined to using data for the national sample for the comparison groups. Houston was also included in both the 1979 and the 1983 SMSA samples. Although Houston does not make a good comparison group for the Mariel quasi experiment (Houston had a housing construction boom from 1979 to 1982), I can use Houston's observations to check for the comparability of the two samples. The coefficients in the fixed-effects estimation are virtually identical. Despite the smaller size, the national subsamples do an excellent job of identifying the price change differentials. 
Table 5.-Price Changes by Unit Type, 1979-1983 (Miami vs. Metro U.S.)

\begin{tabular}{lcc}
\hline \hline 1983 Interaction with: & $\log ($ Rent $)$ & $\begin{array}{c}(2) \\
\text { Rent }\end{array}$ \\
\hline 1st quartile $\times$ Miami & $0.055^{* *}(0.024)$ & $13.648^{* *}(4.554)$ \\
2nd quartile $\times$ Miami & $0.097^{* *}(0.021)$ & $20.204^{* *}(3.980)$ \\
3rd quartile $\times$ Miami & $0.076^{* *}(0.021)$ & $15.557^{* *}(4.062)$ \\
4th quartile $\times$ Miami & $0.022 \quad(0.023)$ & $7.265 \quad(4.463)$ \\
1st quartile & $0.193^{* *}(0.009)$ & $33.082^{* *}(1.676)$ \\
2nd quartile & $0.036^{* *}(0.008)$ & $14.184^{* *}(1.492)$ \\
3rd quartile & $0.006 \quad(0.008)$ & $9.667 * *(1.443)$ \\
4th quartile & $-0.046^{* *}(0.008)$ & $-8.757^{* *}(1.484)$ \\
$R$-square & 0.876 & 0.894 \\
$N \times T$ & 18518 & 18518 \\
\hline
\end{tabular}

Coefficients for interactions with 1983 dummy. Data from national AHS (United States) and SMSA AHS (Miami). Units are matched between samples (balanced panel). Includes unit fixed effects. I calculate the distribution of rents in each MSA. Units are classified according to their rent quartile in their MSA in 1979 (controlling for the number of bedrooms). The regression allows for a different after (or 1983 dummy) coefficient for each of the quartiles, and for a separate Miami $\times$ after coefficient for each of the quartiles in Miami.

the boatlift, we would expect to see part or all of this rent effect in 1981. The shortcoming of the 1979-1981 comparison is that the sample sizes are considerably reduced. Yet, the results strongly point in the same direction: there was a major rent increase in the Miami MSA, whereas in the comparison groups there were no real changes. The regressions on the log of rents suggest a slightly larger short-run differential increase of $8.37 \%, 12.04 \%$, and $11.82 \%$ in the Miami rental prices with respect to the Florida ones, previoussimilar-growth, and U.S. comparison groups, respectively. Thus, as expected, the boatlift had a strong initial impact on rental prices that was only starting to be arbitraged away by $1983 .{ }^{24}$

The model introduced earlier also predicts that the price impact of an unskilled immigration shock should be higher for lower-quality units. To assess the impact of the boatlift on the different value segments of the housing market, I make use of the longitudinal nature of the 1979-1983 AHS samples. Table 5 studies the price change by rent quartile. I use the observations from the Miami SMSA 1979 and 1983 samples to get an accurate picture of the Miami market. The comparison group is the rest of the metropolitan United States. ${ }^{25}$ Within an MSA, and controlling for the number of bedrooms in the housing unit, I rank all rental units according to their rental price in 1979. I proceed to calculate the cutoff rent levels that define a rent quartile by MSA in 1979.

\footnotetext{
${ }^{24}$ All the qualitative results in this section are robust to possible outliers in the data: median regressions yield very similar results in all cases. Results for the Southern group (10.7\%) and the South Atlantic group $(11 \%)$ are also remarkably close.

${ }^{25}$ Since I have to use observations from the National AHS for the comparison groups, I chose the rest of the United States as the relevant comparison group. On one hand (table 4), the results for the overall boatlift impact are similar to those for the other comparison groups. More importantly, only the U.S. group contains enough observations for each rent quartile to estimate the differentials with precision.
}

I then assign each unit to a quartile according to these 1979 benchmarks. The regressions show the coefficient of the interaction of a 1983 dummy with a dummy for each quartile on real rents and allow for a differential Miami effect. Units that were in the first, second, and third quartiles in 1979 were significantly affected in Miami. Such rental units tended to cater to individuals with income below the median. Households with income below the Miami median were a majority in 1979 in the first three quartiles of the rent distribution. Most households with incomes above the Miami median owned their houses rather than renting (see table 3). Yet the share of households with incomes above the median was $50 \%$ in the fourth rent quartile. As hypothesized, the Miami effect was not significant in these most expensive units that catered to higher income households. The results are broadly consistent with the hypothesis of a disproportionate impact on housing units catering to individuals with lower incomes; notice, though, that the relation between initial rent and the 1983 Miami differential is not monotonic: units in quartile 1 seem to have experienced a somewhat lower differential hike than units in quartiles 2 and 3.26

Table 6 investigates whether the Mariel immigration shock had a concentrated impact in those areas of the city occupied by poor Hispanic renters. One would expect the new Cuban immigrants to have settled mainly in areas that were affordable and predominantly Hispanic. Competition for ethnic-specific amenities should have driven up rents in those areas in the short run, until the marginal lower-income Hispanic renter was indifferent between them and the rest of the city. This is an interesting exercise, because other hypothetical contemporaneous shocks in the Miami housing market that could explain my previous results do not have this implication. The AHS data do not provide any geo-

\begin{tabular}{|c|c|c|}
\hline $\begin{array}{r}\text { TABLE 6.-RENTAL UNITS WIT } \\
\text { HOUSEHOLD INCOME IN }\end{array}$ & $\begin{array}{l}\text { ENTERS BELOW ONE- } \\
\text { 79: HISPANIC-OCCUF }\end{array}$ & $\begin{array}{l}\text { LF MiaMi's MEDIAI } \\
\text { vs. OTHERS }\end{array}$ \\
\hline & $\begin{array}{l}(1) \\
\text { Rent }\end{array}$ & $\begin{array}{c}(2) \\
\log (\text { Rent })\end{array}$ \\
\hline 1983 dummy & $18.056^{* *}(4.241)$ & $0.072 * *(0.028)$ \\
\hline $1983 \times$ Hispanic in 1979 & $12.326 * *(6.191)$ & $0.082 * *(0.041)$ \\
\hline Constant & $187.234 * *(2.429)$ & $5.131 * *(0.016)$ \\
\hline Unit fixed effects & Yes** & Yes** \\
\hline $\begin{array}{l}R \text {-square } \\
N \times T\end{array}$ & $\begin{array}{r}0.887 \\
822\end{array}$ & $\begin{array}{r}0.832 \\
822\end{array}$ \\
\hline $\begin{array}{l}\text { Units } \\
\text { Hispanic-occupied in } 1979\end{array}$ & $\begin{array}{l}411 \\
167\end{array}$ & $\begin{array}{l}411 \\
167\end{array}$ \\
\hline
\end{tabular}

Data from Miami SMSA sample. I match rental units that appear in both the 1979 and 1983 samples and have complete information for rents and family income (balanced panel). Regressions include unit fixed effects and are calculated using sample weights. The table focuses on units for which the surveyed family income in 1979 was below Miami's median (in the AHS). The estimated median family income in the Miami MSA was $\$ 14,472$ in 1979 . The Hispanic dummy controls for units that were occupied by for other poor families (families with incomes below the Miami median). 
Figure 6.-Persons per Bedroom in Rental Units
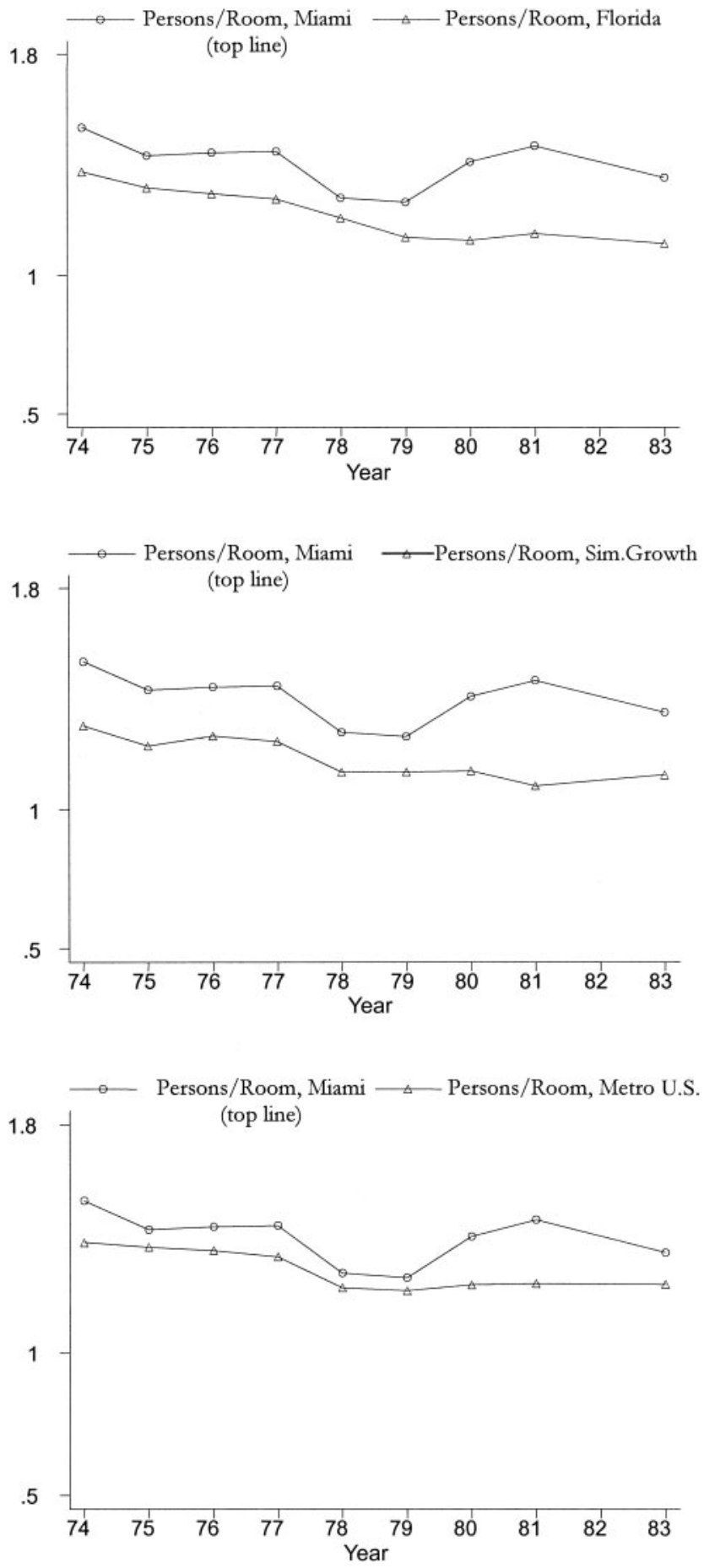

graphical information besides central city location. Nevertheless we can again make use of the longitudinal nature of the sample to address this question.

Let us start by considering only Miami's rental units occupied by households with incomes below one-half the median household income in 1979. This is where one would expect the immigration shock to have the strongest effect. Among these, I identify the housing units occupied by
Hispanic renters in 1979. Some of these units may not have been located in a predominantly Hispanic area. But the probability that they were located in a Hispanic area is certainly higher than for the other units.

Table 6 thus presents the differences-in-differences estimates of the change in prices in units occupied by poor Hispanic renters in 1979, including housing unit fixed effects. A plausible comparison group is formed by the units occupied in 1979 by non-Hispanic poor households (that is, by households with incomes below onehalf of Miami's median). In the first column we can see that rents in poor Hispanic households rose $\$ 12$ more than in poor non-Hispanic households. As shown in column (2), this corresponds to an extra $8 \%$ over the price paid by other poor renters. The evidence is consistent with the prior expectation that the impact of the boatlift was strongest in poor Hispanic areas of the Miami MSA.

\section{B. Further Results: Densities, Supplies, and Turnover}

In this section I try to explain how the market accommodated the unexpected increased demand for rental units in the short run. Much of the adjustment right after the boatlift occurred in terms of occupation densities.

Figure 6 shows us the trends of density in rental units (measured in persons per bedroom in the market) in the AHS samples from 1974 to 1983 . This measure of density takes into account both vacancy rates (which cannot be measured independently with accuracy in the national AHS samples) and density in occupied units. The pictures show steadily declining densities and a nearly constant differential between Miami and the rest of Florida until 1979. In 1980 and 1981 there was a sharp increase in persons per bedroom in the Miami sample. ${ }^{27}$ This differential had been substantially reduced by 1983 .

\begin{tabular}{|c|c|c|c|}
\hline \multicolumn{4}{|c|}{$\begin{array}{l}\text { TABLE 7.-DifFERENCES IN PERSONS PER ROOM IN THE A } \\
1979-1981\end{array}$} \\
\hline & \multicolumn{3}{|c|}{ Persons per Bedroom } \\
\hline & $\begin{array}{l}(1) \\
\text { Florida }\end{array}$ & $\begin{array}{l}\text { (2) } \\
\text { Similar Growth }\end{array}$ & $\begin{array}{l}\text { (3) } \\
\text { Metro U.S. }\end{array}$ \\
\hline Miami & $0.127 *(0.071)$ & $0.128 * *(0.064)$ & $0.046 \quad(0.058)$ \\
\hline 1981 & $0.014 \quad(0.049)$ & $-0.050 \quad(0.032)$ & $0.024 * *(0.008)$ \\
\hline Miami $\times 1981$ & $0.189 * *(0.084)$ & $0.253 * *(0.028)$ & $0.179 * *(0.069)$ \\
\hline Constant & $1.138 * *(0.042)$ & $1.137 * *(0.028)$ & $1.219 * *(0.007)$ \\
\hline $\begin{array}{l}R \text {-square } \\
N \times T\end{array}$ & $\begin{array}{r}0.0247 \\
1041\end{array}$ & $\begin{array}{r}0.0315 \\
1532\end{array}$ & $\begin{array}{r}0.001 \\
24396\end{array}$ \\
\hline $\begin{array}{l}\text { (\% Miami } \\
\text { increase) }\end{array}$ & $14.93 \%$ & $19.99 \%$ & $14.13 \%$ \\
\hline
\end{tabular}


Figure 7.-New Housing Permits (Housing Units/Population)

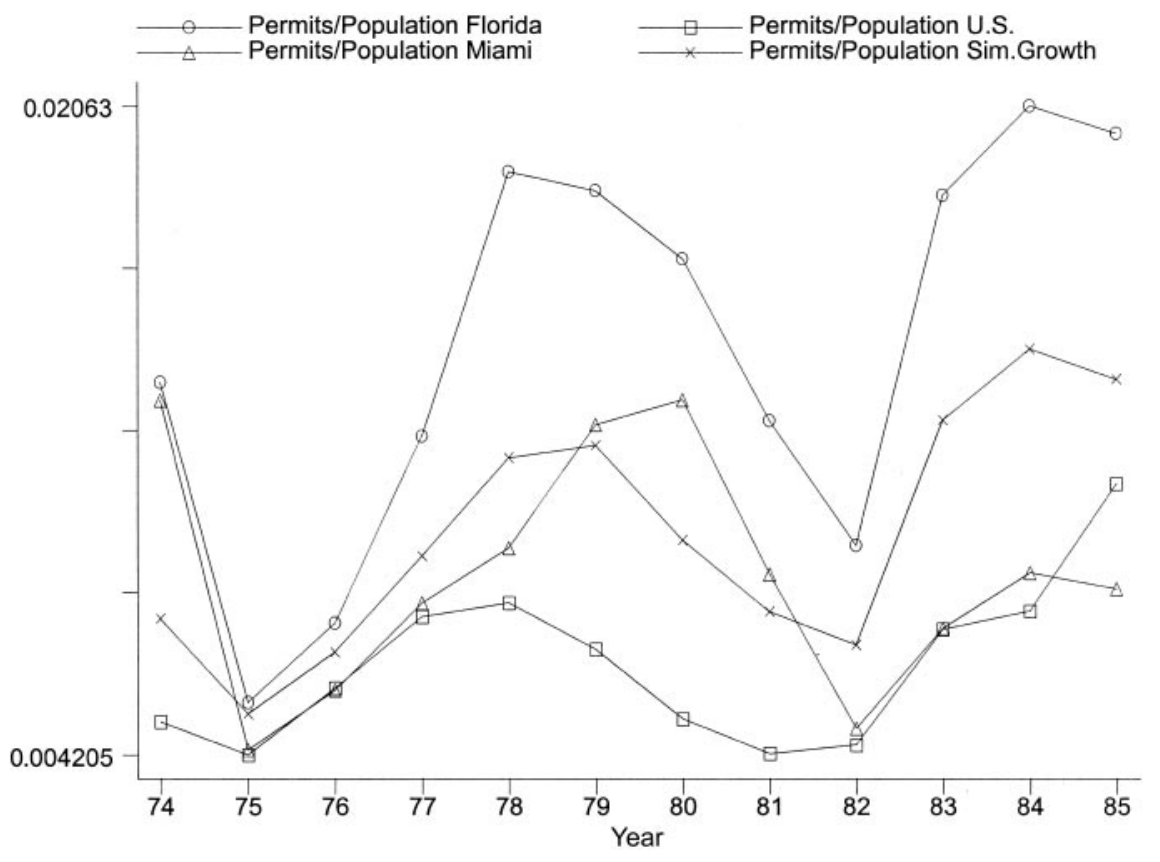

Table 7 shows the results of a simple differences-indifferences regression analysis to approximate the change in densities in rental units in the Miami area between 1979 and 1981. Other variables might have longer adjustment periods. But if the unexpected population growth associated with the boatlift was the cause of increased rents in 1981, the density (the number of people per unit of housing space) should be shown to have increased right after the boatlift. The last row in table 7 offers the point estimate of the differential percentage change in persons per room in $\mathrm{Mi}-$ ami. Taking the rest of Florida as the relevant comparison group, the estimated change in persons per available rental bedroom is about $14 \%$. This magnitude is comparable with my previous discussion about the relative size of the immigration shock in the rentals market: a $7 \%-12 \%$ increase. Indeed, neither $7 \%$ nor $12 \%$ can be rejected at the $5 \%$ confidence level as the percentage change in persons per bedroom after the boatlift. Thus, the data suggest that the new immigrants were absorbed in the short run entirely through higher occupation densities: lower vacancy rates and higher densities in the units occupied by newly arrived immigrants. These results, again, point to the importance of the immigration shock in explaining the changes in rental prices found in the previous section.

Figure 7 illustrates the evolution of the supply of new housing in Miami and the comparison areas, using registered new housing start permits per capita. There was no major supply response right after the boatlift. Just as in the comparison cities, there was a big dip in new housing permits after 1980, which was attributable to the economic

1979 and no change whatsoever in 1980 and 1981: the density differentials remain stable. slowdown. In 1983, though, the new-housing-permits series in the comparison areas went back to their pre-1981 levels and actually surpassed them. In Miami there was some reactivation in 1983, but new starts didn't return to their 1979-1980 levels.

As illustrated in figure 6, occupation densities reverted rapidly, after 1981, to pre-1980 levels. In fact, as of the end of 1983 the vacancy rates for rental units measured from the AHS $(9.7 \%)$ were substantially higher than the initial ones in $1979(6.7 \%){ }^{28}$ Out-migration was the main mechanism explaining the partial convergence of rents from 1981 to 1983 , given the scarce and slow adjustment in the housing supply in the immediate years after the boatlift. ${ }^{29}$

${ }^{28}$ The AHS apartment vacancy rates for the metropolitan United States (except Miami) were $5.98 \%$ in 1979 and $6.67 \%$ in 1983.

${ }^{29}$ Table B3 in Appendix B illustrates this. The Miami metropolitan area exhibits very low population growth rates just after the Mariel boatlift.

Table 8.--IMPact on Net Wages

\begin{tabular}{|c|c|c|c|}
\hline & $\begin{array}{c}\text { (1) } \\
1979 \text { Share of } \\
\text { Rent over } \\
\text { Household } \\
\text { Wage Income }\end{array}$ & $\begin{array}{c}(2) \\
\text { Simulated Share } \\
\text { of Rent over } \\
\text { Household } \\
\text { Wage Income } \\
\text { after Boatlift }\end{array}$ & Difference \\
\hline All & $23.60 \%$ & $25.02 \%$ & $-1.42 \%$ \\
\hline Lowest wage quartile & $52.50 \%$ & $56.27 \%$ & $-3.77 \%$ \\
\hline 2nd wage quartile & $28.67 \%$ & $30.96 \%$ & $-2.30 \%$ \\
\hline 3rd wage quartile & $20.00 \%$ & $21.26 \%$ & $-1.26 \%$ \\
\hline Top wage quartile & $13.85 \%$ & $14.81 \%$ & $-0.96 \%$ \\
\hline
\end{tabular}

All data from 1979 SMSA AHS. The 1979 share of rent on wage income is calculated by multiplying monthly rent payments by 12 and dividing by total household wage income (for all complete observations of renter-occupied units). The simulated ex post share is calculated by applying the corresponding percentage change in each unit's rents by rent quartile (as estimated in table 5). For the results for the different wage quatiles, I divide the valid ample (observations on four groups of the same magnitude according to the level of household wage income. 
TABle 9.-Post-Boatlift Evolution

\begin{tabular}{|c|c|c|c|}
\hline \multicolumn{4}{|c|}{$\begin{array}{c}\text { Panel A } \\
\text { Nominal House Price Appreciation }\end{array}$} \\
\hline & & \multicolumn{2}{|c|}{$\%$ Appreciation } \\
\hline & & 1980-1983 & 1980-1987 \\
\hline Rochester, NY MSA & & 23.50 & 74.02 \\
\hline Orlando, FL MSA & & 21.33 & 36.28 \\
\hline Fort Myers-Cape Coral, FI & & 21.30 & 41.16 \\
\hline Sarasota-Bradenton, FL MS & & 20.90 & 42.55 \\
\hline Tampa-St. Petersburg-Clea & er, FL MSA & 20.28 & 42.24 \\
\hline Jacksonville, FL MSA & & 19.72 & 40.99 \\
\hline Atlanta, GA MSA & & 18.74 & 51.58 \\
\hline Fort Lauderdale, FL PMSA & & 18.29 & 30.76 \\
\hline West Palm Beach-Boca R & FL MSA & 16.27 & 28.23 \\
\hline Melbourne-Titusville-Palm & FL MSA & 14.99 & 25.60 \\
\hline Greensboro-Winston-Salen & h Point, NC MSA & 14.44 & 48.61 \\
\hline Daytona Beach, FL MSA & & 12.40 & 25.78 \\
\hline Miami, FL PMSA & & 10.10 & 18.58 \\
\hline Appleton-Oshkosh-Neenah & MSA & 6.63 & 22.78 \\
\hline Tucson, AZ MSA & & 4.04 & 19.84 \\
\hline Milwaukee-Waukesha, WI & & -2.14 & 10.63 \\
\hline Spokane, WA MSA & & -6.60 & 9.50 \\
\hline \multicolumn{2}{|l|}{ U.S.-Urban CPI } & 20.30 & 37.33 \\
\hline \multicolumn{4}{|c|}{$\begin{array}{l}\text { Panel B } \\
\text { HUD Fair Market Rent Evolution (1983-1990) }\end{array}$} \\
\hline & Fair rent 1983 & 1983 & 1990 \\
\hline Rochester, NY MSA & 359 & 100.00 & 146.24 \\
\hline Atlanta, GA MSA & 372 & 100.00 & 145.16 \\
\hline Tucson, AZ MSA & 378 & 100.00 & 144.44 \\
\hline \multicolumn{4}{|l|}{$\begin{array}{l}\text { Tampa-St. Petersburg- } \\
\text { Clearwater, FL }\end{array}$} \\
\hline MSA & 368 & 100.00 & 133.15 \\
\hline Spokane, WA MSA & 350 & 100.00 & 124.29 \\
\hline Orlando, FL MSA & 407 & 100.00 & 123.59 \\
\hline Jacksonville, FL MSA & 374 & 100.00 & 121.93 \\
\hline $\begin{array}{l}\text { Greensboro-Winston- } \\
\text { Salem-High Point, } \\
\text { NC MSA }\end{array}$ & 325 & 100.00 & 120.92 \\
\hline \multicolumn{4}{|l|}{ Fort Lauderdale, FL } \\
\hline PMSA & 491 & 100.00 & 120.77 \\
\hline \multicolumn{4}{|l|}{ Milwaukee-Waukesha, } \\
\hline \multicolumn{4}{|l|}{ Appleton-Oshkosh- } \\
\hline Neenah, WI MSA & 333 & 100.00 & 118.92 \\
\hline South Bend, IN MSA & 346 & 100.00 & 115.90 \\
\hline Miami, FL PMSA & 494 & 100.00 & 114.98 \\
\hline \multicolumn{4}{|l|}{ West Palm Beach- } \\
\hline MSA & 449 & 100.00 & 113.59 \\
\hline U.S.-Urban CPI & & 100.00 & 129.10 \\
\hline
\end{tabular}

Data from Freddie Mac and HUD. Housing price changes are from the third quarter in 1980 to the thir quarter in 1983 and 1987.

\section{Rents and Real Wages}

How substantive were the changes in rents that this paper documents compared with the wage income of previous residents in the Miami area? Table 8 addresses this question for the subsample of renters in the 1979 Miami metropolitan sample. The first column in table 8 presents the median ${ }^{30}$ share of rental expenditures over total household wage

\footnotetext{
${ }^{30}$ Several observations report housing costs greater than their total family wages. The median is robust to these outlying observations.
}

income, as reported in the AHS. The second column applies the estimated impact of the boatlift to the full distribution of rents in 1979 and recalculates the median share of rental expenditures as a share of wage income. In the first row, in line with the results in table 4 (panel A), I use a $7 \%$ increase for all rents. Column (3) of table 8 shows the percentage impact on net wages (defined as wages minus rents), under the assumption of no changes in the consumption of housing services. The overall impact was small: a $1.42 \%$ reduction in net wages. It is interesting to express this magnitude as an elasticity with respect to the percentage change in population associated with the immigration shock. As detailed earlier, estimates on the impact of the boatlift on Miami's population range from $3.8 \%$ to $5.2 \%$. Thus, according to the results in this paper, an unexpected immigration shock that amounts to $1 \%$ of the city's population can be associated with a $0.27 \%-0.37 \%$ reduction in average net wages in the short run.

The results become somewhat more interesting if we allow for heterogeneity. Rows 2 to 5 present the results for each of the four quartiles in the wage distribution. I also allow for heterogeneity in the boatlift's impact on rents: for each unit I apply the percentage rent increase that corresponds to that housing unit's rent quartile (table 5). I then divide the sample into four quartiles according to reported household wage income, conditional on being a renter. The table reports the median share of rents over wages within each quartile before the boatlift and the simulated share afterward. The wage impact of the boatlift was somewhat more substantial for renters in the lower wage quartile: $3.77 \%$ (an implied elasticity with respect to percentage change in population of $0.72-1$ ). Most of the difference in the impact is due to the initial higher share of rents over wages for these households. The smallest impact corresponds to households in the top wage quartile: 0.96 percent (an elasticity of $0.18-0.25$ ).

\section{Housing Prices and Rents: Solving an Apparent Paradox}

While rents increased after the Mariel immigration shock, relative housing prices collapsed in Miami. The first column in panel A of table 9 illustrates this. The table shows the evolution of the Freddie Mac housing price index for

TABle 10.- ShIFTS In Demand FOR Quality

\begin{tabular}{cccccc}
\hline \hline & \multicolumn{4}{c}{ Vacancy Rate } \\
\cline { 2 - 3 } $\begin{array}{c}\text { Rent } \\
\text { Quartile }\end{array}$ & Miami & Metro U.S. & & \multicolumn{2}{c}{1983} \\
\cline { 2 - 3 } \cline { 5 - 6 } 1st & $0.111(0.014)$ & $0.051(0.004)$ & $0.054(0.010)$ & $0.047(0.003)$ \\
2nd & $0.054(0.010)$ & $0.047(0.003)$ & $0.089(0.015)$ & $0.060(0.004)$ \\
3rd & $0.040(0.008)$ & $0.060(0.004)$ & $0.108(0.017)$ & $0.066(0.004)$ \\
4th & $0.061(0.012)$ & $0.073(0.004)$ & $0.138(0.017)$ & $0.063(0.004)$ \\
\hline
\end{tabular}

Vacancy rates for rental housing units. Data from Miami 1979 and 1983 SMSA AHS. 
TABLE 11.-ShifTS IN ETHNic COMPOSITION

\begin{tabular}{|c|c|c|c|c|c|c|c|c|}
\hline $\begin{array}{l}\text { Household } \\
\text { Head Group }\end{array}$ & \multicolumn{3}{|c|}{1979} & \multicolumn{3}{|c|}{1983} & $\begin{array}{c}1979 \\
(7) \\
\text { Matched } \\
\text { Rentals }\end{array}$ & $\begin{array}{c}1983 \\
(8) \\
\text { Matched } \\
\text { Rentals }\end{array}$ \\
\hline Hispanic & $0.216(0.008)$ & $0.327(0.011)$ & $0.264(0.007)$ & $0.252(0.010)$ & $0.389(0.012)$ & $0.311(0.008)$ & $0.324(0.012)$ & $0.359(0.013)$ \\
\hline $\begin{array}{r}\text { Black (non- } \\
\text { Hispanic) }\end{array}$ & $0.093(0.006)$ & $0.174(0.009)$ & $0.128(0.005)$ & $0.105(0.007)$ & $0.179(0.010)$ & $0.137(0.006)$ & $0.183(0.010)$ & $0.199(0.011)$ \\
\hline Other & $0.006(0.001)$ & $0.008(0.002)$ & $0.007(0.001)$ & $0.005(0.002)$ & $0.010(0.002)$ & $0.006(0.001)$ & $0.009(0.007)$ & $0.008(0.002)$ \\
\hline $\begin{array}{l}\text { Vacant/out of } \\
\text { the market }\end{array}$ & $0.142(0.007)$ & $0.067(0.006)$ & $0.110(0.005)$ & $0.176(0.009)$ & $0.097(0.008)$ & $0.142(0.006)$ & $0.068(0.012)$ & $0.121(0.009)$ \\
\hline$N$ & 3523 & 2052 & 5575 & 2541 & 1717 & 4258 & 1592 & 1592 \\
\hline
\end{tabular}

Standard errors of the estimated means in parenthesis. Means and s.e. estimated using sample weights. Data from Miami SMSA AHS sample: 1979 and 1983 . The "matched rentals" sample corresponds to the units sampled both in 1979 and 1983 .

Miami, available comparison cities, and available other MSAs in Florida. Miami has one of the lowest housing price appreciations between the third quarter of 1980 and the third quarter of 1983. Changes in housing prices in Dade County were 10 percentage points lower than the increase in the U.S. urban CPI during the same period. A striking contrast is offered by the changes in prices in the Fort Lauderdale MSA, just 35 miles north of Miami, which mimic general price level increases. How can we reconcile the apparent paradox of rapid rent hikes and housing price devaluation? Housing prices capitalize the present value of future rents. Despite the short-run pressures on the rental market, participants in the housing market must have been expecting reduced future demand (because of native out-migration and reduced in-migration) to outweigh the demand induced by the immigration shock. Indeed, population growth rates in Miami after the boatlift were relatively low (see appendix B, table B3). Card (1990) points out that "the Mariels may have displaced other migrants from within the United States who could have been expected to move to Miami."

The theoretical model in the paper predicts that the increase in rents (or the negative impact on wages) caused by an unskilled immigration shock will eventually be exactly offset by out-migration of unskilled natives. In the short run, welfare is reduced, but in the long run, the welfare impact is negligible (the national long-run housing supply is assumed to be completely elastic). Thus, ceteris paribus, there is no reason to expect higher or lower rents in the long run from an immigration shock as long as there are marginal mobile natives. Housing values should not change much, even in the short run. Even if the Mariel immigrants displaced unskilled natives because of competition in the labor and housing markets, there seems to be no reason to expect lower long-run population growth rates and lower house values.

These facts suggest that something besides rental prices and wages was important in explaining the actual and expected population turnover. Indeed, Table 10 shows the shift in the demand for housing quality. I consider rental units by quartile in the rent distribution. The first quartile corresponds to those apartments with lowest rental prices. I compare vacancy rates in Miami and the rest of the metropolitan United States in 1979 and 1983. Vacancies in lowend units decreased dramatically in Miami, whereas the vacancy rate for higher-quality units increased. These changes contrast with relatively stable profiles in the rest of the United States. The data clearly reflect the demand shift in the lower quality segment, as hypothesized, but also indicate decreased demand for higher qualities. Demand for housing quality is a good proxy for permanent income. The moving costs of persons living in rental units are smaller than those for homeowners. The data, therefore, are consistent with the idea that wealthy persons were starting to move out of the Miami metropolitan area in 1983.

Table 11 explores the population turnover in terms of ethnic characteristics. There was a remarkable shift, especially in the rental market. In particular there was an increase in the proportion of Hispanic renter-occupied units and vacancies stemming from the out-migration of white non-Hispanic renters. The number of rental units for which the household head was Hispanic increased by 6.2 percentage points between 1979 and 1983. The number of vacant units increased by 3 percentage points. Remarkably, the number of units with a white Anglo head of household decreased a full 9.7 percentage points in only these four years. Notice that this pattern was not a consequence of Hispanics moving into newly built units but represented a real turnover. In columns (7) and (8) I present the ethnic composition of head of household for apartments that were rented in 1979 and that appear again in the 1983 sample: the reader is looking at data for the very same dwellings.

This evidence is consistent with a perception of the Mariel immigration shock as a negative amenity by higher income and predominantly white previous residents. Contemporary accounts from the Miami and national press could have helped to associate the Mariel refugees with 
crime and other social problems. A good portrait of the ethnic tensions in Miami created by the big inflows of immigrant population, especially the Mariel boatlift, can be found in Grenier and Stepick (1992) and Portes and Stepick (1993). The Washington Post (1998) and US News (1996) provide anecdotal views on what they denominate the "white flight" from the Miami MSA.

The evidence from the Miami case is also consistent with Filer's (1992) study. This author reports that "white native workers are less likely than other ethnic groups to find the cities where the immigrants settle attractive." In the long run, then, immigration may interact with existing ethnic residential preferences (Cutler, Glaeser, and Vigdor, 1999). Although the evidence is consistent with a story in which the Mariel immigrants were perceived as a negative amenity by some existing residents, more work is needed to study the relationship between immigration and the demand for residential segregation.

In areas and events in which high-income residents perceive low-skilled immigration inflows as a negative amenity, the demand for higher-quality units will decrease in the long run. The existence of vacant units of higher quality will put downward pressure on the prices of all housing units. The filtering down of higher-quality housing to the poor (O'Flaherty, 1993) will accelerate. Some unskilled persons, including immigrants, will occupy housing units of higher quality. In the long run, this may imply lower rents for all units, including lower-quality homes. Indeed, rent growth in Miami from 1983 to 1990 , as measured by the FMR, ${ }^{31}$ was slower than in the comparison groups.

In the short run, therefore, immigration shocks put pressure on local housing markets and rents are pushed up. The longer-run effect of immigration on rents and prices, as the Miami case suggests, may depend on whether immigration is perceived as a negative amenity by previous residents. The interaction between immigration and preferences for residential segregation cannot be identified by means of the methodology used in this paper. Clearly, this is an important question that requires further research.

\section{Conclusions}

This paper identifies the short-run impact of immigration on local housing. Recent immigrants tend to demand lowerquality rental housing and are willing to bid out natives for these kinds of dwellings in the port-of-entry metropolitan areas.

I find that the level of immigration in U.S. metropolitan areas in 1990 was correlated with increases in rents for dwellings of moderate quality between 1990 and 1992 .

To address concerns over the endogeneity of immigration inflows, and following the approach in Card (1990), I make

\footnotetext{
${ }^{31}$ Unreported analysis of the 1986 AHS also shows that by 1986 all of Miami's 1979-1983 differential growth was completely depleted, and there was actually a reverse differential in favor of the comparison groups.
}

use of the Mariel boatlift, which increased the renter population in Miami by about $9 \%$ in only one year. The Mariel boatlift immigration shock increased rental prices in the Miami area by $8 \%$ to $11 \%$ between 1979 and 1981. This differential was still $7 \%$ in 1983 . The quantitative adjustment in the short run was mainly achieved with higher residential densities in the rental market. Units that were occupied by poor Hispanic renters in 1979 may have experienced higher rent hikes. Units in the highest quartile in the 1979 Miami rent distribution were not affected by the rent hikes.

Even in the absence of a reduction in nominal wages, the rent hike decreased real wages. The results may contribute to an explanation of the moving decisions of marginal native workers in the short to medium run, although the impact on real wages was modest. My estimates of the wage impact range from $1 \%$ for persons in the upper quartile of the renters' wage distribution to $3.8 \%$ for persons in the lowest quartile. The results qualify the findings of the labor economics literature on the local impact of immigration in the short run. Unpredicted immigration inflows do change local real wages in the very short run.

In the absence of further immigration, the long-run evolution of rents and housing prices depends on whether immigrants are perceived as a negative amenity. This might have been the case in Miami after the Mariel boatlift. Relative housing prices, which capitalize future changes in rents, moved in the opposite direction from rents, even in the short run. There was a remarkable change in the ethnic composition of the city's dwellers in only 4 years.

These results suggest several avenues for future research on this topic. To understand the longer-run impact of sustained immigration on housing markets, future work should be devoted to studying whether the qualitative and quantitative results in this paper are generalizable to other metropolitan areas and time periods and whether sustained, expected immigration inflows have similar effects. ${ }^{32}$ It would also be relevant to learn more about the response of housing supply. It is particularly important to examine whether supply responds to sustained unskilled immigration inflows by, for instance, shifting construction toward multiunit dwellings. Finally, it seems important to understand what is the amenity value of immigration for previous residents in general. Miami's experience around 1980 might be special, and the methodology used in this paper constrains the validity of the results to the short run. Nevertheless, the Miami case study suggests that labor and housing markets are not the only factor behind the moving decisions of natives in the long run. Social interactions are clearly important, and housing markets give us information about their value.

\footnotetext{
${ }^{32}$ An effort in that direction can be found in Saiz (2002)
} 


\section{References}

Altonji, Joseph, and David Card, "The Effects of Immigration on the Labor Market Outcomes of Natives," in John M. Abowd and Richard Freeman (Eds.), Immigration, Trade, and the Labor Market (Chicago: The University of Chicago Press, 1991).

Blanchard, Olivier J., and Lawrence Katz, "Regional Evolutions," Brookings Papers on Economic Activity 0:1 (1992), 1-61.

Borjas, George, "The Economics of Immigration," Journal of Economic Literature 32:4 (1994), 1667-1717.

Heaven's Door: Immigration Policy and the American Economy (Princeton: Princeton University Press, 2000).

"Does Immigration Grease the Wheels of the Labor Market?" Brookings Papers on Economic Activity 2001:1 (2001).

Borjas, George, and Lynette Hilton, "Immigration and the Welfare State: Immigrant Participation in Means-Tested Entitlement Programs," The Quarterly Journal of Economics 111:2 (1996), 575-604.

Borjas, George, Richard Freeman, and Lawrence Katz, "Searching for the Effect of Immigration on the Labor Market," The American Economic Review 86:2 (1996), 246-251.

Braid, Ralph M., "The Short Run Comparative Statics of a Rental Housing Market," Journal of Urban Economics 10 (1981), 286-310.

Brueckner, Jan K., "The Structure of Urban Equilibria: A Unified Treatment of the Alonso-Muth-Mills Model," (pp. 821-845), in E. S. Mills (Ed.), Handbook of Regional and Urban Economics 2 (Amsterdam: Elsevier, 1988).

Burnley, Ian, Peter Murphy, and Robert Fagan, Immigration and Australian Cities (Sydney: The Federation Press Ltd., 1997).

Callis, Richard, "Moving to America-Moving to Homeownership," Current Housing Reports H121/97-2 (Census Bureau, 1997).

Card, David, "The Impact of the Mariel Boatlift on the Miami Labor Market," Industrial \& Labor Relations Review 43:2 (1990), 245257.

Cutler, David M., Edward L. Glaeser, and Jacob Vigdor, "The Rise and Decline of the American Ghetto," Journal of Political Economy 107:3 (1999), 455-506.

Filer, Randall K., "Immigrant Arrivals and the Migratory Patterns of Native Workers," in George J. Borjas and Richard B. Freeman (Eds.), Immigration and the Workforce (Chicago: The University of Chicago Press, 1992).

Friedman, Samantha, Emily Rosenbaum, and Michael Schill, "The Housing Conditions of Immigrants in New York City," Fannie Mae working paper, Fannie Mae Foundation (1998).

Grenier, Guillermo, and Alex Stepick, Miami Now!: Immigration, Ethnicity, and Social Change (University Press of Florida, 1992).

Hansen, Jorgen, and Magnus Lofstrom, "Immigrant Assimilation and Welfare Participation: Do Immigrants Assimilate Into or Out of Welfare?" CEPR discussion paper no. 2430 (2000).

Hoxby, Caroline, "Do Immigrants Crowd Disadvantaged American Natives Out of Higher Education?" in Daniel S. Hammermesh and Frank D. Bean (Eds.), Help or Hindrance: The Economic Implications of Immigration for African Americans (New York: Russel Sage Foundation, 1998).

Joint Center for Housing Studies of Harvard University, The State of the Nation's Housing 2000 (Cambridge, MA: Harvard University, 2000).

Jones-Correa, Michael, "Immigrants, Blacks and Cities," in Y. AlexAssensoh and L. Hanks (Eds.), Black Politics in America (New York: New York University Press, 2000).

Kennedy, Peter E., "Estimation with Correctly Interpreted Dummy Variables in Semilogarithmic Equations," American Economic Review 71:4 (1981), 801

Ley, David, and Judith Tuchener, "Immigration and Metropolitan House Prices in Canada," Research on Immigration and Integration in the Metropolis (Vancouver Center of Excellence) working paper no. 99-09 (1999).

Muller, Thomas, and Thomas J. Espenshade, The Fourth Wave: California's Newest Immigrants (Washington: The Urban Institute Press, 1985).

National Research Council, The New Americans: Economic, Demographic and Fiscal Effects of Immigration (Washington: National Academy Press, 1997).

O'Flaherty, Brendan, "An Economic Theory of Homelessness and Housing," Journal of Housing Economics 4 (1993), 13-49.
Making Room: The Economics of Homelessness (Cambridge, MA: Harvard University Press, 1996).

Portes, Alejandro, and Alex Stepick, "Unwelcome Immigrants: The Labor Market Experiences of 1980 (Mariel) Cuban and Haitian Refugees in South Florida," American Sociological Review 4:4 (1985), 493-514.

City on the Edge: The Transformation of Miami (University of California Press, London, 1993).

Roback, Jennifer, "Wages, Rents, and the Quality of Life," Journal of Political Economy 90:6 (1982).

Saiz, Albert, "The Impact of Immigration on American Cities," Ph.D. thesis, Harvard University (2002).

Simon, Julian L., The Economic Consequences of Immigration (Ann Arbor: The University of Michigan Press, 1999).

Sweeny, James L., "Quality, Commodity Hierarchies, and Housing Markets," Econometrica 42:1 (1974), 47-168.

Thave, Suzanne, "Les étrangers et leurs logements," INSEE Première no. 689 (December 1999).

Topel, Robert H., "Local Labor Markets," Journal of Political Economy 94:3 (1986), 111-143.

US News, "America's New Melting Pot" (April 29, 1996).

Washington Post, "A White Migration North from Miami" (November 11, 1998).

Weiss, Yoram, "High Skill Immigration: Some Lessons from Israel," Tel Aviv University mimeograph (2000).

Zax, Jeffrey S., "Immigration, Race, and Space," in Daniel S. Hamermesh and Frank D. Bean (Eds.), Help or Hindrance: The Economic Implications of Immigration for African Americans (New York: Russel Sage Foundation, 1998).

\section{Appendix A}

Recall the equations defining the housing market equilibrium:

$$
\begin{aligned}
& V^{S}\left(Q^{*}\right)+A_{M}+W_{M}^{S}-\overline{U_{S}}=V^{U}\left(Q^{*}\right)+A_{M}+W_{M}^{U}\left(N_{U}^{*}\right)-\overline{U_{U}}, \\
& N_{U}^{*}=\int_{0}^{Q^{*}} S\left(\psi^{U}(Q), Q\right) d Q .
\end{aligned}
$$

The parameter of interest is $W_{M}^{S}$. Introducing the price equation (the bid rent for the unskilled) in equation (5), we have

$$
N_{U}^{*}=\int_{0}^{Q^{*}} S\left(V^{U}(Q)+A_{M}+W_{M}^{U}\left(N_{U}^{*}\right)-\overline{U_{U}}, Q\right) d Q .
$$

Similarly, we can obtain the number of skilled individuals in equilibrium:

$$
N_{S}^{*}=\int_{Q^{*}}^{\bar{Q}} S\left(V^{S}(Q)+A_{M}+W_{M}^{S}-\overline{U_{S}}, Q\right) d Q .
$$

In equilibrium we obtain $N_{U}^{*}$ as a function of $Q^{*}$. Differentiating equation (A1) with respect to $Q^{*}$ yields

$$
\begin{aligned}
N_{U}^{* \prime}\left(Q^{*}\right)= & S\left(\psi^{U}\left(Q^{*}\right), Q^{*}\right) \\
& +\int_{0}^{Q^{*}} S_{1}\left(\psi^{U}(Q), Q\right) W_{M}^{U \prime}\left(N_{U}^{*}\right) N_{U}^{* \prime}\left(Q^{*}\right) d Q .
\end{aligned}
$$

We can rearrange this to obtain

$$
N_{U}^{* \prime}\left(Q^{*}\right)=\frac{S\left(\psi^{U}\left(Q^{*}\right), Q^{*}\right)}{1-\left[W_{M}^{U}\left(N_{U}^{*}\right) \int_{0}^{Q^{*}} S_{1}\left(\psi^{U}(Q), Q\right) d Q\right]} .
$$

If population does not affect wages, then when the equilibrium $Q^{*}$ increases, the increase of unskilled population is equal to the number of housing units of quality $Q^{*}$ in the old equilibrium. If there are wage effects (so that the bidding curve for the poor is differentially reduced), a 
reduction in the supply for all qualities up to $Q^{*}$ dampens the unskilled population increase.

Differentiating the equation (4), $Q^{*}$ being a function of $W_{M}^{S}$ in equilibrium, yields

$$
\begin{aligned}
& V^{S \prime}\left(Q^{*}\right) \cdot Q^{* \prime}\left(W_{M}^{S}\right)+1=V^{U \prime}\left(Q^{*}\right) \cdot Q^{* \prime}\left(W_{M}^{U}\right) \\
& \quad+W_{M}^{U \prime}\left(N_{U}^{*}\right) \cdot N_{U}^{* \prime}\left(Q^{*}\right) \cdot Q^{* \prime}\left(W_{M}^{U}\right) .
\end{aligned}
$$

Rearranging, we have

$$
Q^{*^{\prime}}\left(W_{M}^{U}\right)=\frac{1}{V^{U^{\prime}}\left(Q^{*}\right)-V^{S^{\prime}}\left(Q^{*}\right)+W_{M}^{U^{\prime}}\left(N_{U}^{*}\right) \cdot N_{U}^{* \prime}\left(Q^{*}\right)}<0 .
$$

Thus, an increase in the skilled wage in location $M$ reduces the quality cutoff level for which the skilled outbid the unskilled (gentrification). Al the prices increase, and the unskilled are not displaced one for one, because a lower unskilled population increases wages, allowing this group to bid higher and to increase supply for the lowest qualities.

Now consider an immigration shock of $N_{I}$ unskilled persons. In the short run mobility costs are arbitrarily high. In the short-run equilibrium the dwelling supply needs to adjust in order to house the native and the immigrant populations.

Lemma 1. The new bid curves will equal the old ones plus a constant

Proof. The unskilled population competes for better qualities. In equilibrium all have to be indifferent between locations. The bid curve is determined by the native population (immigrants do not need to bid higher than natives). Call their utility level $\overline{\overline{U_{U}}}$. Let $\psi_{2}^{i}(Q)$ be the new rent bid for group $i$. We need to have

$$
V^{U}(Q)+A_{M}+W_{M}^{U}\left(N_{U}^{*}+N_{I}\right)-\psi_{2}^{U}(Q)=\overline{\overline{U_{U}}}
$$

and thus

$$
\begin{aligned}
\psi_{2}^{U}(Q)= & V^{U}(Q)+A_{M}+W_{M}^{U}\left(N_{U}^{*}+N_{I}\right)-\overline{\overline{U_{U}}} \\
\psi_{2}^{U}(Q)= & V^{U}(Q)+A_{M}+W_{M}^{U}\left(N_{U}^{*}\right)+\overline{U_{U}}+\left\{W_{M}^{U}\left(N_{U}^{*}+N_{I}\right)\right. \\
& \left.-\overline{\overline{U_{U}}}-W_{M}^{U}\left(N_{P}^{*}\right)-\overline{U_{U}}\right\} \equiv \psi^{U}(Q)+C^{U} .
\end{aligned}
$$

Similarly we can obtain

$$
\psi_{2}^{S}(Q)=\psi^{S}(Q)+C^{S} .
$$

Lemma 2. If $C^{S}<0$, then $Q^{* *}<Q^{*}$.

Proof. The number of skilled does not change in the short run, and we have

$$
\int_{Q^{* *}}^{\bar{Q}} S\left(\psi^{S}(Q)+C^{S}, Q\right) d Q=\int_{Q^{*}}^{\bar{Q}} S\left(\psi^{S}(Q), Q\right) d Q .
$$

Assume, towards a contradiction, that $C^{S}<0$ and $Q^{* *}>Q^{*}$. From equation (A11),

$$
\begin{gathered}
\int_{Q^{* *}}^{\bar{Q}}\left[S\left(\psi^{S}(Q)+C^{S}, Q\right)-S\left(\psi^{S}(Q), Q\right)\right] d Q \\
-\int_{Q^{*}}^{Q^{* *}} S\left(\psi^{S}(Q), Q\right) d Q=0 .
\end{gathered}
$$

Because $C^{S}<0$, we have $\left[S\left(\psi^{S}(Q)+C^{S}, Q\right)-S\left(\psi^{S}(Q), Q\right)\right]<0 \forall Q$. Also $\int_{Q^{*}}^{Q^{* *}} S\left(\psi^{S}(Q), Q\right) d Q>0$. Then

$$
\begin{gathered}
\int_{Q^{* *}}^{\bar{Q}}\left[S\left(\psi^{S}(Q)+C^{S}, Q\right)-S\left(\psi^{S}(Q), Q\right)\right] \\
-\int_{Q^{*}}^{Q^{* *}} S\left(\psi^{S}(Q), Q\right) d Q<0 .
\end{gathered}
$$

Lemma 3. If $C^{S}<0$, then $C^{U}>0$.

Proof. Assume $C^{S}<0$ and $C^{U}<0$. The unskilled population is equal to $N_{I}+N_{U}^{*}$, and we need

$$
N_{I}+N_{U}^{*}=\int_{0}^{Q^{* *}} S\left(\psi^{U}(Q)+C^{U}, Q\right) d Q .
$$

Using lemma 2 and equation (5), we obtain

$$
\begin{aligned}
N_{I}= & \int_{0}^{Q^{* *}}\left[S\left(\psi^{U}(Q)+C^{U}, Q\right)-S\left(\psi^{U}(Q), Q\right)\right] d Q \\
& -\int_{Q^{* *}}^{Q^{*}} S\left(\psi^{U}(Q), Q\right) d Q .
\end{aligned}
$$

Because $C^{U}<0$, we have $\left[S\left(\psi^{U}(Q)+C^{U}, Q\right)-S\left(\psi^{U}(Q), Q\right)\right]<0$ and $\int_{Q^{* *}}^{Q^{*}} S\left(\psi^{U}(Q), Q\right) d Q>0$, implying that $N_{I}<0$, which contradicts our assumption of a positive immigration shock.

Lemma 4. $C^{S}>0$.

Proof. Assume that $C^{S}<0$. By Lemma 2, $Q^{* *}<Q^{*}$. By Lemma 3 , $C^{U}>0$. The quality cutoff level that separates the unskilled from the skilled $\left(Q^{* *}\right)$ is such that

$$
\psi^{S}\left(Q^{* *}\right)+C^{S}=\psi^{U}\left(Q^{* *}\right)+C^{U} .
$$

Using equations (1) and (3) to substitute for the old price schedules at $Q^{* *}$, subtracting equation (4), and manipulating yields

$$
\left[V^{U}\left(Q^{*}\right)-V^{U}\left(Q^{* *}\right)\right]-\left[V^{S}\left(Q^{*}\right)-V^{S}\left(Q^{* *}\right)\right]=C^{U}-C^{S} .
$$

It is clear that $C^{U}-C^{S}>0$, but, as we assumed $d V^{S}(Q) / d Q>$ $d V^{U}(Q) / d Q \forall Q$, we have

$$
\left[V^{U}\left(Q^{*}\right)-V^{U}\left(Q^{* *}\right)\right]-\left[V^{S}\left(Q^{*}\right)-V^{S}\left(Q^{* *}\right)\right]<0 .
$$

Lemma 5. If $C^{S}>0$, then $Q^{* *}>Q^{*}$.

Proof. Similar to Lemma 2.

Lemma 6. $C^{U}>0$.

Proof. Assume $C^{U}<0$. By Lemma 4, $C^{S}>0$ and by Lemma 5, $Q^{* *}$ $>Q^{*}$. Notice that we have

$$
\left[V^{U}\left(Q^{*}\right)-V^{U}\left(Q^{* *}\right)\right]-\left[V^{S}\left(Q^{*}\right)-V^{S}\left(Q^{* *}\right)\right]>0 .
$$

But $C^{U}-C^{S}<0$, which contradicts equation (A17).

Proposition. $C^{U}>C^{S}$ (the price increase is higher for the unskilled individuals)

Proof. By previous lemmas, $C^{U}, C^{S}>0$ and $Q^{*}<Q^{* *}$, so

$$
C^{U}-C^{S}=\left[V^{U}\left(Q^{*}\right)-V^{U}\left(Q^{* *}\right)\right]-\left[V^{S}\left(Q^{*}\right)-V^{S}\left(Q^{* *}\right)\right]>0 .
$$


Appendix B

TABLE B1.-DifFEREnCES-IN-DifFEREnCES: Miami vs. Houston (1979-1983)

\begin{tabular}{|c|c|c|c|c|}
\hline & \multicolumn{2}{|c|}{ SMSA AHS Samples } & \multicolumn{2}{|c|}{ National AHS Samples } \\
\hline & $\begin{array}{c}(1) \\
\text { Rent }\end{array}$ & $\begin{array}{c}(2) \\
\log (\text { Rent })\end{array}$ & $\begin{array}{c}(3) \\
\text { Rent }\end{array}$ & $\begin{array}{c}(4) \\
\log (\text { Rent })\end{array}$ \\
\hline 1983 & $0.059 \quad(1.991)$ & $0.006 \quad(0.011)$ & $-2.810 \quad(6.115)$ & $0.002 \quad(0.029)$ \\
\hline Miami $\times 1983$ & $25.154 * *(2.969)$ & $0.090 * *(0.015)$ & $27.339 * *(7.877)$ & $0.087 * *(0.038)$ \\
\hline Constant & $232.226^{* *}(1.125)$ & $5.359 * *(0.007)$ & $242.314 * *(2.964)$ & $5.389 * *(0.014)$ \\
\hline $\begin{array}{l}\text { Fixed effects } \\
R \text {-square } \\
N\end{array}$ & $\begin{array}{c}\text { Yes** } \\
0.883 \\
4772\end{array}$ & $\begin{array}{r}\text { Yes** } \\
0.8916 \\
4772\end{array}$ & $\begin{array}{r}\text { Yes** } \\
0.8873 \\
690\end{array}$ & $\begin{array}{r}\text { Yes** } \\
0.8567 \\
690\end{array}$ \\
\hline
\end{tabular}

Standard errors in parentheses. Sample weights used in all regressions.

Table B2.-Evolution of Real Income per Capita Growth Rates in Miami, The United States, and the Rest of Florida

\begin{tabular}{|c|c|c|c|c|c|c|c|c|c|c|c|c|c|}
\hline & \multicolumn{13}{|c|}{ Growth Rate (\%/yr.) } \\
\hline & 1977 & 1978 & 1979 & 1980 & 1981 & 1982 & 1983 & $\begin{array}{c}\text { Annualized } \\
1977-1983\end{array}$ & 1984 & 1985 & 1986 & 1987 & $\begin{array}{l}\text { Annualized } \\
1983-1987\end{array}$ \\
\hline Miami & 1.59 & 4.74 & -0.36 & -2.27 & -1.82 & -1.43 & 2.42 & 0.38 & 2.69 & 1.69 & 1.88 & 2.74 & 1.86 \\
\hline United States & 2.93 & 3.87 & -0.09 & -2.77 & 0.40 & -0.98 & 2.19 & 0.77 & 5.29 & 2.53 & 2.92 & 1.84 & 3.94 \\
\hline Jacksonville & 1.70 & 2.62 & -1.13 & -2.07 & 1.46 & 1.08 & 3.53 & 1.01 & 5.05 & 3.18 & 3.07 & 2.23 & 3.19 \\
\hline Orlando & 1.69 & 5.64 & 0.06 & 0.80 & 0.22 & 0.80 & 3.97 & 1.87 & 2.90 & 3.20 & 3.29 & 1.41 & 2.91 \\
\hline Fort Lauderdale & 4.83 & 5.61 & 1.30 & 0.53 & 1.65 & -3.01 & 3.25 & 1.99 & 4.33 & 2.03 & 3.38 & 2.21 & 3.09 \\
\hline Tampa-St. Petersburg & 4.89 & 4.79 & 0.67 & 0.41 & 1.51 & -0.60 & 3.86 & 2.20 & 3.89 & 2.34 & 3.11 & 0.85 & 2.47 \\
\hline West Palm Beach-Boca Raton & 4.28 & 7.02 & 2.24 & 1.08 & 4.05 & -1.88 & 7.20 & 3.38 & 4.16 & 4.92 & 3.35 & 4.19 & 3.31 \\
\hline
\end{tabular}

Data in 1982-1984 average dollars using the BLS urban CPI index. Nominal MSA income per capita data from the BEA.

Table B3.-Evolution of Population Growth in Miami, The United States, and the Rest of Florida

\begin{tabular}{|c|c|c|c|c|c|c|c|c|c|c|c|c|c|}
\hline & \multicolumn{13}{|c|}{ Growth Rate (\%/yr.) } \\
\hline & 1977 & 1978 & 1979 & 1980 & 1981 & 1982 & 1983 & $\begin{array}{c}\text { Annualized } \\
1977-1983\end{array}$ & 1984 & 1985 & 1986 & 1987 & $\begin{array}{l}\text { Annualized } \\
1983-1987\end{array}$ \\
\hline United States & 1.06 & 1.11 & 1.18 & 0.99 & 0.96 & 0.92 & 0.87 & 1.01 & 0.87 & 0.89 & 0.93 & 0.90 & 1.38 \\
\hline Jacksonville & 1.50 & 0.79 & 2.73 & 1.88 & 1.73 & 1.94 & 2.71 & 1.89 & 2.71 & 2.97 & 3.09 & 2.54 & 2.46 \\
\hline Miami & 0.73 & 2.76 & 2.58 & 5.22 & 0.98 & 0.98 & 0.66 & 1.98 & 0.66 & 1.21 & 1.38 & 1.66 & 1.15 \\
\hline Fort Lauderdale & 3.92 & 4.65 & 4.02 & 2.85 & 2.03 & 1.70 & 1.44 & 2.94 & 1.44 & 1.99 & 1.90 & 2.29 & 1.91 \\
\hline Tampa-St. Petersburg-Clearwater & 2.67 & 3.66 & 3.41 & 3.10 & 2.70 & 3.00 & 2.90 & 3.06 & 2.90 & 2.81 & 2.48 & 2.27 & 2.27 \\
\hline Orlando & 3.23 & 4.25 & 4.14 & 3.97 & 3.77 & 4.43 & 4.52 & 4.04 & 4.52 & 4.04 & 4.23 & 4.21 & 4.02 \\
\hline West Palm Beach-Boca Raton & 3.70 & 6.28 & 6.32 & 5.95 & 4.08 & 3.34 & 3.96 & 4.80 & 3.96 & 4.20 & 4.20 & 4.18 & 3.29 \\
\hline
\end{tabular}

Data from Census County Population estimates (Miami-Dade County) and the BEA (rest of metropolitan areas) 